\title{
Credit constraints and demand for remedial education: Evidence from Tanzania
}

CAGE working paper no. 545

March 2021

\author{
Konrad Burchardi \\ Jonathan de Quidt \\ Selim Gulesci \\ Munshi Sulaiman
}




\title{
CREDIT CONSTRAINTS AND DEMAND FOR REMEDIAL EDUCATION: EVIDENCE FROM TANZANIA*
}

\section{Konrad Burchardi ${ }^{\dagger}$ Jonathan de Quidt ; Selim Gulescis; Munshi Sulaiman}

February 26, 2021

\begin{abstract}
We study how credit constraints affect access to a remedial education program for girls. We gave an unconditional cash transfer to randomly selected households, then measured their Willingness To Pay (WTP) for the program. In the control group average WTP was 3,300 Tanzanian Shillings, seven percent of per-capita monthly expenditures. For those identified at baseline as able to borrow, the cash transfer increases WTP by three percent. For those unable to borrow, the cash transfer increases WTP by 27 percent. We conclude that credit constraints limit access to educational programs, and may increase inequality of outcomes.
\end{abstract}

\footnotetext{
*We thank DFID for funding under the Girls' Education Challenge (GEC) program and BRAC for supporting and enabling this research. Sara Banfi, Mattia Chiapello, Francesca Larosa, Andrea Giglio, and in particular Camilla Fabbri and Lisette Swart provided outstanding research assistance. We thank Tessa Bold, Francesco Loiacono, and Abhijeet Singh, and seminar audiences at EBRD, University of Milan-Bicocca, Trinity College Dublin, and the IIES Speed Brown Bag and Development Tea, for valuable comments. The experiment received ethical clearance from the Bocconi University Ethics committee and is registered at the AEA RCT registry, https://doi.org/10.1257/rct.5695-1.0. All remaining errors are our own.

${ }^{\dagger}$ Institute for International Economic Studies, Stockholm University, BREAD, CEPR, CESifo, ThReD; E-mail: konrad.burchardi@iies.su.se

${ }^{\ddagger}$ Institute for International Economic Studies, Stockholm University, CAGE, CEPR, CESifo, and ThReD; Email: jonathan.dequidt@iies.su.se

§ Department of Economics, Trinity College, Dublin, BREAD, CEPR, EUDN, J-PAL; E-mail: gulescis@tcd.ie

IBRAC Institute of Governance and Development; E-mail: munshi.sulaiman@brac.net
} 


\section{Introduction}

Despite considerable improvements in access to primary education, enrollment rates fall sharply at the secondary level in many developing countries, especially for children from poorer families. In Tanzania, the setting of our study, the attendance rate in primary education is $76 \%$, but falls to only $23 \%$ in secondary education (TDHS, 2015-16). The latter figure masks substantial heterogeneity: the secondary school attendance rate is $41 \%$ among children from the top wealth quintile while it is only $6 \%$ among those in the lowest quintile. A similar pattern is observed in many countries (Filmer and Pritchett, 1999). Given empirical estimates of returns to secondary education in Tanzania of around 15\% per year (Montenegro and Patrinos, 2014) these figures suggest immense lost potential.

Remedial education programs targeting vulnerable children have emerged as a possible way to ameliorate inequalities in educational attainment; and are being implemented by many governments and non-governmental organizations around the world (e.g. Jayachandran, 2014; Banerjee et al., 2007, 2016; Muralidharan et al., 2019). By assisting students that are lagging behind or at risk of dropping out, remedial education programs may help alleviate learning shortfalls and enable pupils to stay in school. They will ameliorate educational inequalities if they effectively support children from poorer families. However, such programs need to be funded, and attempts to charge for the service might jeopardize this objective in settings where ability or willingness to pay is low. As a consequence even effective interventions may be discontinued in the absence of continued donor funding. For example, the highly effective, subsidized MindSpark centers evaluated in Muralidharan et al. (2019) were forced to close down as insufficiently many families were willing or able to pay the subsidized price.

What keeps families from investing in their children's education? One possible explanation is credit constraints. Despite high returns, constrained families may not be able to finance school or program fees or other complementary inputs. To the extent that credit access is unequally distributed in the population, this will stifle social mobility and enhance inequality. A competing hypothesis is that other correlates of household income, such as the early-childhood parental environment, affect children's cognitive and non-cognitive abilities, and eventual schooling outcomes (Heckman and Carneiro, 2002). Evidence from developed countries suggests credit constraints may be of second-order importance for progression to higher education and better labor market outcomes (Heckman and Mosso, 2014). But they may be of first-order importance in developing countries, where credit constraints are thought to limit take-up of productive investment opportunities (e.g. Banerjee and Newman, 1993; de Mel et al., 2008; Beaman et al., 2015).

We study how credit constraints affect families' investment in a remedial education program 
in Tanzania. As part of its efforts to improve girls' education outcomes, the NGO we collaborated with runs free study clubs for girls aged 12-14, corresponding to cohorts who should be attending the final two years of primary education. The NGO was interested in implementing a participation fee of 3,000 Tanzanian Shillings (TSh, PPP USD 4.06) to support long-run program sustainability, but was concerned about how this might affect access. We worked with them to elicit households' Willingness to Pay (WTP) for the program at 69 clubs in villages that did not previously have one. Prior to WTP elicitation, half of households received an unconditional cash transfer, intended to relax the effects of credit constraints on program access. We analyze how this transfer affects WTP, and how it interacts with credit constraints measured at baseline.

In each village we surveyed a representative sample of eligible girls and the heads of their households at baseline. At the end of the survey, we invited the girl and household head to a village meeting about girls' education. They received a lottery ticket for a cash prize of 3,200 TSh, described as a "thank you" for taking the survey, to be drawn during those village meetings. This lottery is our experimental treatment of interest. We interpret winning the lottery as lowering the opportunity cost of capital for credit-constrained households. It ensures that even completely credit constrained households would be able to pay at least as much as the program fee if they wanted to.

The village meetings started with the draw of the lottery to award prizes to $50 \%$ of eligible attendees. Subsequently the program officers explained the study clubs in detail. Last, we elicited WTP to join the club through a "multiple price list" variant of the Becker-DeGroot-Marschak mechanism (Becker et al., 1964). Girls filled out the instrument along with the adult who had joined them, usually a household head, so we interpret the response as the household's WTP. ${ }^{1}$

The experiment and data allow us to (a) measure the household's WTP for their daughter to participate in the study club, (b) identify the causal effect of the cash transfer on WTP, (c) study the correlations between WTP and measures of credit constraints, and (d) examine heterogeneity of the effect of the cash transfer with respect to credit constraints.

What should we expect to see if credit constraints are depressing demand for educational programs? Suppose household $i$ values the program at $V_{i}$ units of consumption. After accounting for other spending needs (such as consumption or other higher-return investment opportunities) their investable funds are $A_{i}\left(B_{i}\right)$, where $B_{i}$ is credit available to them. It is

\footnotetext{
${ }^{1}$ Once completed, we revealed the village's randomized price (either 0 or 3,000 TSh), which had been kept in a sealed envelope and was unknown to the participants and implementing team until then. This determined who would gain access to the club: those whose WTP was greater than or equal to the price could join, paying the price; those whose WTP was below the price would pay nothing and receive nothing. This ensures that truthful reporting of WTP is a (weakly) dominant strategy.
} 
natural to assume that $A^{\prime} \geq 0$ : the more easily they can access credit, the less pressing will be their unmet spending needs and the more they can afford to invest in a new opportunity. As a result, the maximum amount they are willing to pay for the program is $W T P=\min \left\{A_{i}\left(B_{i}\right), V_{i}\right\}$.

Our cash transfer treatment can be thought of as increasing investable funds to $A_{i}\left(B_{i}\right)+T$, so the WTP of treated households now equals $\min \left\{A_{i}\left(B_{i}\right)+T, V_{i}\right\}$. It is thus predicted to have no effect on unconstrained households' (those with $A_{i} \geq V_{i}$ ) WTP, while constrained households with $A_{i}<V_{i}$ will increase their WTP. The effect is intermediate for those lying close to the constraint, with $A_{i}<V_{i}<A_{i}+T$. Thus, we expect the cash transfer will increase WTP for the program, but that this effect will be concentrated among the credit constrained.

We find four main results. First, households are willing to pay for the remedial education program. Non lottery-winning households are willing to pay around 3,300 TSh (PPP USD 4.47 ) on average, corresponding to $1.4 \%$ of total monthly household expenditure, or $7 \%$ of monthly per capita expenditure in our sample, and is approximately equal to the 3,000 TSh program fee tested during the study. There is substantial heterogeneity: $9 \%$ of households were willing to pay 10,000 TSh, while $16 \%$ were not willing to pay anything.

Second, winning the 3,200 TSh lottery prize increases average WTP by around 300 TSh, or 9\%. Third, there is a negative association between WTP and two proxies for credit constraints, both measured at baseline: a household-level dummy for "inability to borrow for an important expenditure," and an index of four dummy variables measuring credit constraints. Among lottery losers, inability to borrow is associated with approximately 500 TSh lower WTP.

Fourth, the lottery treatment interacts strongly with credit constraints measured at baseline. While WTP is strongly decreasing in baseline credit constraints for lottery losers, among lottery winners the association disappears, consistent with the cash transfer alleviating their credit constraints. The average effect of the lottery is almost entirely driven by credit constrained households: those who report being able to borrow increase WTP by only 3\% (roughly 120 TSh) when they win, while those who cannot borrow increase WTP by $27 \%$ (roughly $850 \mathrm{TSh}$ ). This interaction effect is robust to controlling for interactions with a host of observable characteristics that might be correlated with credit constraints and WTP, such as distance to school, girl's cognitive skills, preferences, and household expenditures or poverty. This suggests that the heterogeneity we find is not proxying other girl- or household-level characteristics.

The collection of evidence suggests that credit constraints are an important driver of low takeup of educational investments.

The paper is related to the literature on the role of credit constraints in suppressing profitable investments in general and education investments in particular. While the association 
between family income and schooling outcomes has been documented in a variety of contexts, evidence on the role of credit constraints is mixed and is largely from developed countries (Heckman and Carneiro, 2002; Cameron and Taber, 2004; Dahl and Lochner, 2012; Caucutt and Lochner, 2020). In developing countries, a number of studies highlight the importance of prices and credit constraints for the take-up of health products (Kremer and Miguel, 2007; Hoffmann, 2009; Hoffmann et al., 2009; Ashraf et al., 2010; Cohen and Dupas, 2010; Dupas, 2014; Tarozzi et al., 2014; Fischer et al., 2019; Berry et al., 2020), insurance (Casaburi and Willis, 2018), and fuel-efficient stoves (Berkouwer and Dean, 2020). Evidence in the context of education is largely based on (downward) changes in school fees through vouchers (e.g. Angrist et al., 2006), scholarships (e.g. Kremer et al., 2009) or the abolition of school fees (e.g. Deininger, 2003; Riphahn, 2012; Bold et al., 2014). One exception is Berry and Mukherjee (2019) whose contemporaneous study provides evidence on the demand for private tutoring in urban India, using a two-part pricing design. They show that higher WTP for private tutoring is associated with higher utilization, while lower prices reduce dropout rates.

Methodologically, the study is closely related to Casaburi and Willis (2018), who estimate the effect of a cash-transfer on demand for insurance, and especially Berkouwer and Dean (2020), who elicit WTP for cookstoves and study how WTP is affected when participants gain access to credit.

The paper also relates to the literature on cash transfers for education (see Baird et al. (2014) and Bastagli et al. (2016) for recent reviews). This literature mostly focuses on conditional cash transfers, which are linked to education takeup (e.g. Evans et al. (2020)). These studies tend to focus on enrollment and participation in education, and typically find positive effects. Benhassine et al. (2015) study a cash transfer that is "labeled" as being for education, and find it has similar effects on school participation to conditional transfers. In contrast, the lottery in our experiment is deliberately not labeled as being for education, and is instead framed as compensation for participation in the survey, and in that sense is more closely related to unconditional cash transfer programs, some of which have been studied. Haushofer and Shapiro (2016) find in Kenya that large cash transfers increased monthly educational spending, but the effect is small relative to the size of the transfer ( $\$ 1$ PPP versus transfers of $\$ 404$ or \$1,525 PPP). We also find modest average impacts, albeit larger relative to the size of the transfer, but importantly, our findings demonstrate strong heterogeneity. The lottery payment increases educational investments strongly, and almost exclusively, for households that our baseline survey identifies as credit constrained. 


\section{Background and Methodology}

In this section we describe the program, sample selection, WTP elicitation, some implementation challenges, our main credit constraints measures, and randomization balance checks. Appendix B provides additional details.

\subsection{The Program}

We study a remedial education program implemented by an NGO in Tanzania. ${ }^{2}$ The central aim of the program is to improve learning outcomes of girls at risk of dropping out of school, or who have recently dropped out, and to increase enrolment rates. As part of this effort, the NGO established study clubs, designed to provide subject-based tutoring in Mathematics and English to girls in school but at risk of dropping out, as well as out-of-school girls. According to the program design, tuition for in-school girls who are in their final two years of primary education was scheduled to take place in the afternoon hours, three times a week, for three hours. The tutoring for out-of-school girls was to take place in the mornings, five days a week, for three hours. In addition, the NGO would register the out-of-school girls under the Institute of Adult Education, enabling them to complete their Form 1 and 2 courses. The tutoring was facilitated by trained teachers who were paid an honorarium for their work. The tutoring follows the primary education curriculum and is intended to prepare pupils for the Tanzanian secondary school entrance exams. ${ }^{3}$

The clubs are situated inside villages to make them easily accessible. In the afternoon hours, the clubs are used as safe spaces for both in-school and out-of-school girls where they come together, interact, forge bonds and support each other in their studies. In addition to subject-based tutoring, the clubs provide life skills training through peer mentoring. One of the club members is selected and trained by the NGO on topics related to health, sanitation, contraception and soft skills (like attitudes, expectations, self-confidence and cognitive skills). She then trains other club members on these issues. ${ }^{4}$

\subsection{Sample Selection}

Here we briefly summarize how we arrive at our analysis sample. See Appendix B.1 for a step-by-step description.

\footnotetext{
${ }^{2}$ The NGO we collaborated with is BRAC Tanzania.

${ }^{3}$ The program is similar to remedial education programs aiming to provide a pathway for out-of-school youth to return to formal education. In the East African context, these programs are often provided by NGOs, labeled as "second-chance," "bridging" or "re-entry" programs (Mastercard Foundation, 2018). As an alternative, families can hire private tutors to assist youth prepare for the secondary school entrance exams. Private tutoring is obviously an expensive option and available only for pupils from higher socio-economic classes.

${ }^{4}$ This component is similar to the life skills training offered by BRAC clubs in Uganda (see Bandiera et al., 2020). A crucial difference is that while the clubs we study offer tutoring to younger girls, the Ugandan clubs offered vocational training to slightly older girls, aiming to create employment opportunities.
} 
The NGO implemented the remedial education program at 20 branches in the regions of Dar es Salaam, Mwanza, Shinyanga, Tabora and Singida. In September 2013 we randomly selected eight study branches. Within those branches the NGO's field staff identified 105 villages close to potential treatment schools. ${ }^{5}$ The program was to be assigned at the school level, so either all, or no villages connected to a given school would receive the program. Villages were grouped in 42 "clusters," with villages close to the same school assigned to the same cluster. Of those, we randomly selected 27 clusters containing 69 villages as study locations. The remaining villages were to be control villages for the purpose of program evaluation, and not relevant to this paper.

We randomized study villages, stratified by the NGO's branch offices, into two groups: in 36 the club would be free, and in 33 there would be a one-time fee of 3,000 TSh. ${ }^{6}$

We conducted a short census of girls aged 11 to 18 in the villages in November 2013. The census collected information on the number of girls, their households, and their schooling status. The census served a sampling frame for the baseline survey. Girls in the census were screened for program eligibility. ${ }^{7}$ Within the 69 study villages, the census sample consisted of 5,968 girls, of whom 5,048 were eligible for program participation.

The baseline survey was conducted in December 2013. The main respondent to the baseline survey was the selected girl. At the end of the survey a short additional module was addressed to the household head, eliciting information on household demographics and socio-economic status. We aimed to sample only one girl per household, except where the number of available girls was small. In addition, due to challenges finding participants, in some cases we allowed for a limited amount of convenience sampling ( 53 girls fall into this category). Our full baseline sample contains 1,717 girls.

At the end of the baseline survey, girls received a lottery ticket for a prize of 3,200 TSh if they came to an information meeting about the new education program, and they were told that half of eligible (i.e., baseline-surveyed) attendees would win. This lottery was framed as a thank you for taking the survey. The lottery is the treatment of interest in this paper.

\footnotetext{
${ }^{5}$ For simplicity, we always refer to the communities in which clubs are situated as "villages", though in periurban areas a better descriptor would be "neighborhood". Village boundaries were defined by BRAC staff based on candidate sites for a club and do not correspond to a specific administrative unit.

${ }^{6}$ Note that this one-time fee is similar to an annual membership fee, since a given cohort of girls are expected to participate in the tutoring for one year and then take the secondary school entrance exams (i.e. "graduate" from the club). This type of fee structure is common in clubs in our context. For example, BRAC's ELA program evaluated by Bandiera et al. (2020) in Uganda also has a similar fee, although in that case the fee is voluntary and often waived. Non-formal education programs also often charge such one-off fees as a "community contribution".

${ }^{7}$ Eligibility required the girl a) had dropped out of school within the last two years, or was at risk of dropping out (a grade of less than 50\% in Mathematics, Science, or English in the last exam), and b) at least one of i) belongs to a poor household, based on a poverty scorecard for Tanzania, developed by Grameen foundation, ii) has lost one or both parents, iii) displays signs of physical or mental disability, or iv) comes from a minority ethnic group.
} 


\subsection{WTP Elicitation}

The information meetings were organized in June 2014. Appendix B.4 contains the meeting script. All baseline girls from a given village were invited to attend, as well as any other girls living in the village. They were to be accompanied by a household member, ideally the household head. The meeting was described as an information session about the new education program. Of the 1,717 girls in the baseline, 880 attended a WTP meeting, plus 252 non-baseline girls. As we lack survey data for non-baseline girls, and they were not eligible for the lottery, we do not include them in the analysis.

First, we conducted the lottery. Girls who had participated in the baseline survey were eligible. Those who did not bring their lottery ticket were to be issued a new ticket. Prizes were to be awarded through a public draw at which 50\% (rounding up) of tickets would win. Winners were told that they were free to do whatever they wanted with the money.

Afterwards the program officers described the study clubs in detail. It was emphasized that to join the club, girls needed to sign up on the day of the meeting, and that any fee charged for participation was due at the first club meeting.

Last, we elicited WTP to join the club. Participants were told that joining the club might be free or might require a one-time fee. The price had already been decided and it was written inside an envelope that was shown to the audience, but participants were not told about the price distribution. Before the envelope was opened, participants needed to declare their maximum WTP. They were provided with a sheet of paper that contained a list of possible prices, ranging from 0 to 10,000 TSh. The participants were asked to tick "Yes" next to each price they would be willing and able to pay to participate in the club, and to tick "No" for prices that they were not willing/able to pay (this could include that they would join the club only if it was free). If the price in the envelope was equal to or below their WTP, they were required to join the club and pay the fee at the first meeting of the study club. Those whose WTP was below the price would pay nothing and receive nothing. For expected utility maximizers, bidding up to one's true maximum WTP is a weakly dominant strategy.

Our elicitation mechanism is a "multiple price list" variant of the Becker-DeGroot-Marschak mechanism (Becker et al., 1964; Andersen et al., 2006). This implementation helps the participants by breaking down the mechanism into simple take-it-or-leave-it questions. They were reminded that they could not influence the price, and our procedure - where the price was already determined but not revealed - made this very clear. Burchardi et al. (2021) test for optimal bidding under four WTP elicitation mechanisms, including one very similar to ours, with rural participants in Uganda. They find high rates of optimal bidding, averaging $86 \%$, in all four.

In order to check their understanding, this explanation was followed by a practice exercise: 
bars of soap were offered to the audience, and they could be purchased using the same procedure outlined above. After answering a few questions to check their comprehension of the rules, participants were asked to state their WTP for the soap. If the highest price on their answer sheet was higher than the price in the envelope, they were required to buy the soap. ${ }^{8}$

After the soap exercise, the same procedure was applied to the study club. After everyone reported their WTP, the answer sheets ${ }^{9}$ were collected and the price inside the envelope was revealed. Everyone willing to pay at least as much as the price which was in the envelope, was asked to sign a "contract" promising to join the club and to pay the price at the first club meeting.

We have WTP data for 825 of the 880 baseline girls that attended. We infer that the 55 for whom we do not have data chose not to participate in the elicitation. This could be because they were unwilling to participate even at zero price. Our results are robust to assigning zero WTP to these girls (see footnote 13).

\subsection{Implementation Challenges}

In 4 villages lottery winners were not recorded by the enumerators. This leaves us with 65 villages and 805 girls for whom we have WTP and treatment data. In 45 villages implementation was perfect: zero non-baseline girls won, and 50\% (rounding up) of baseline girls won the lottery. In some remaining villages more or fewer than half of eligible attendees were treated, and/or some non-eligible attendees also won the lottery. We provide a detailed breakdown in Appendix B.2. Lottery assignment and implementation issues were not correlated with observables, and we have no reason to believe the lottery itself was not randomized, conditional on deviations from the protocol, so we treat the lottery variable as exogenous in our analysis.

Unexpectedly, after completion of the WTP meetings, the NGO experienced difficulties launching the program as intended, and the launch was delayed by several months in some cases. When it was launched, presumably due to the delay, they had significant difficulties in collecting payment for the club fees, so de facto the clubs became free clubs. This is not an issue for our analysis - the WTP elicitation was incentive-compatible as the delays were unanticipated - but it does mean that we cannot examine outcomes downstream of the WTP elicitation.

\subsection{Credit constraints survey measures}

Our main treatment variable of interest is the lottery treatment, which we interpret as alleviating credit constraints for the treated households. To explore how this treatment

\footnotetext{
${ }^{8}$ Unfortunately we did not collect soap WTP data so cannot examine behavior in this practice round.

${ }^{9}$ See Appendix Figure B.1 for the answer sheet, and B.2 for its English translation
} 
interacts with credit constraints, we construct survey-based measures of credit constraints. In the survey, both girls and household heads were asked separately: "If you needed to borrow money for an important expenditure (e.g. health or school related expenditure), how easy would it be for you to borrow the money?" Options were "easy," "not easy, but possible," and "not possible." If the respondent said "don't know" we code them as missing. This gives us two dummy variables for the girl and two for the household, defined as not possible, and not possible OR not easy. Our first survey measure of credit constraints is the dummy for borrowing "not possible" at the household level. Our second measure is a standardized (to mean zero, standard deviation one) index of the four dummy variables, which we refer to as the credit constraints index. ${ }^{10}$ In terms of the terminology in the introduction, a higher constraints measure is interpreted as a lower value of investable funds, $A_{i}$.

\subsection{Balance Checks}

In the Appendix, we perform a sequence of balance checks capturing each stage of the selection process outlined above. This allows us to assess the representativeness of the sample at each stage of the process. We describe these here and provide further details in Appendix B.3.

Appendix Table A.1 compares all census participants to the marginalized (i.e., eligible) group. Due to the screening, marginalized girls have fewer assets, fewer household members, and lower school attendance in the household.

Appendix Table A.2 compares the marginalized sample to the actual baseline sample. Girls in the baseline sample are more likely to come from households with illiterate female heads and households with fewer girls, and have different composition of household assets. The magnitudes of these differences are generally small.

Appendix Table A.3 shows that the girls who attended the WTP meeting were remarkably similar to the general population of baseline girls on a wide range of covariates.

Appendix Table A.4 provides balancing tests for the lottery randomization. Three out of 18 variables (Raven scores, household size, and one of the "girl" credit constraint dummies) show statistically significant differences at the 10 percent level. Notice that the main analysis of interest estimates the effect of the lottery conditional on the credit constraints variable, and therefore this difference is immaterial for that analysis. Further, standardized differences in covariates between winners and losers are small, mostly less than 0.1 s.d., except for Raven scores and household size (both lower among winners). Overall, we find that imbalances are small and quantitatively unlikely to drive any of our main results.

\footnotetext{
${ }^{10}$ If some of the index components are missing we impute them with sample means, if all are missing we code the index as missing.
} 


\section{Results}

\subsection{Estimation}

To identify the effects of winning the lottery on the demand for the program, we estimate an OLS regression of the form:

$$
\mathrm{WTP}_{i h v}=\beta \cdot \text { Lottery }_{i}+\sum_{j=1}^{65} \gamma_{j} \mathbb{1}(v=j)+\varepsilon_{i h v}
$$

$\mathrm{WTP}_{i h v}$ is the willingness-to-pay (WTP) for girl $i$ from household $h$ in village $v$. Lottery ${ }_{i}$ is a dummy variable equal to 1 if the girl won the lottery, and $\gamma_{j}$ are village fixed effects for the 65 villages in which we have lottery data. The parameter of interest is $\beta$, the average effect on WTP of winning the lottery.

To examine how the lottery treatment interacts with credit constraints, we estimate:

$$
\mathrm{WTP}_{i h v}=\beta \cdot \text { Lottery }_{i}+\lambda \cdot \text { Credit }_{i}+\delta \cdot \text { Lottery }_{i} \cdot \text { Credit }_{i}+\sum_{j=1}^{65} \gamma_{j} \mathbb{1}(v=j)+\varepsilon_{i h v}
$$

where Credit ${ }_{i}$ is a measure of credit constraints. In this specification, $\beta$ identifies the treatment effect when Credit ${ }_{i}$ is zero. For our binary measure these are households who can borrow (either easily or with some difficulty). For our index these are households at the index mean. $\lambda$ identifies the relationship between credit constraints and WTP, for those who lost the lottery. $\delta$ identifies the interaction effect between constraints and lottery win.

Although the lottery outcome was determined by randomization at the girl level, we have some households with multiple participating girls. ${ }^{11}$ Intra-household decisions about different girls may be interrelated, and credit constraints are partially defined at the household level. ${ }^{12}$ In the spirit of clustering at the level of assignment (Abadie et al., 2017), we cluster standard errors at the household level. We report estimates clustered at the village level in Appendix Table A.5.

We also report randomization inference $p$-values for the randomized treatment effect and its interaction with credit constraints. We estimate the coefficient of interest under 10,000 alternative assignments chosen randomly with replacement from the set of possible assignments (given our within-village randomization). The $p$-values are the percentile of the coefficient estimated under the true assignment in the distribution of coefficients estimated under alternative assignments. This corresponds to "randomization-c" in Young (2019).

\footnotetext{
${ }^{11}$ Our analysis sample of 805 girls contains 779 households: 755 with one girl, 22 with two, and two with three.

${ }^{12}$ One measure, the household "cannot borrow" dummy is fixed within household, while the index which depends also on the girl module can in principle vary within household.
} 


\subsection{Demand for Education and Credit Constraints}

Figure 1 displays the demand curve for the program, plotting the fraction of households that would participate at different price levels. If the program were offered for free (i.e. zero price), all households would sign up. ${ }^{13}$ But fees significantly affect take-up. $16 \%$ of households were not willing to pay more than zero. Roughly 50\% were willing to pay the true (not-yet-announced) program fee of 3,000 TSh. Less than $20 \%$ were willing to pay more than 5,000 TSh. Lottery winners have higher WTP, indicated by a first-order shift to the right of the demand curve.

Figure 2 splits the sample according to whether the household head reported at baseline that they cannot "borrow money for an important expenditure." While both subsamples show some response to the lottery, the shift is more pronounced for the credit constrained subsample, in particular this group shows a large increase in the share of households willing to pay high prices (5,000 TSh or more).

Table 1 presents the regression equivalents. Column 1 displays estimates of specification (1) in the full sample for which we have WTP and lottery data. Lottery losers were willing to pay 3,335 TSh on average, around 7\% of monthly per capita expenditures. Winning the lottery increases WTP by 311 TSh, or 9.3 percent ( $p$-value $=0.038$ ) on average.

Column 2 reports estimates for the subsample for whom we observe the dummy indicating the household cannot borrow (this variable is missing if they responded "don't know"). The estimates are very similar for this subsample.

Column 3 uses this sample to estimate heterogenous effects of the lottery (specification (2)). For households with credit access, average WTP among lottery losers is 3,633 TSh, increasing by only 119 TSh or 3\% when they win the lottery. Households without credit access have initial WTP of 3,633 - 522 = 3,111 TSh, and are substantially more responsive to the lottery, increasing WTP by $119+734=853 \mathrm{TSh}$, or $27 \%$, when they win. Thus the difference in WTP between constrained and unconstrained households is smaller among winners than losers.

In columns 4 and 5 we use the credit constraints index to proxy households' credit constraints. Column 4 estimates specification (1) for the subsample where this index is observed, finding very similar point estimates to columns 1 and 2 . In column 5 we control for the index and interact it with the lottery treatment. ${ }^{14} \mathrm{~A}$ one standard deviation increase in

\footnotetext{
${ }^{13}$ This high level of takeup could reflect that attendees were already interested in the new education program, or because they felt joining a free club entailed no particular commitment. It could also be that participants that were not willing to participate, even for free, decided not to participate in the WTP elicitation. 55 out of 880 baseline girls who attended did not provide WTP data, 23 lottery winners and 32 losers. If we assign zero WTP to these girls our coefficient estimates change slightly but remain robust.

${ }^{14}$ Because the index is standardized, the coefficient on lottery win has a different interpretation in columns 3 and 5. In column 3 it is the effect for participants who "can borrow" while in column 5 it is for those at the mean of the index.
} 
credit constraints is associated with 387 TSh lower WTP among lottery losers, while the effect of winning the lottery increases by 432 TSh. The fact that the two coefficients approximately cancel one another implies once again that WTP of lottery winners is relatively insensitive to whether they are credit constrained. ${ }^{15}$

In sum, we find that winning the lottery increased WTP for the program, that this effect is almost entirely driven by the responsiveness of credit constrained households, and that conditional on winning the lottery, WTP is largely insensitive to credit constraints. The latter finding suggests that the lottery was effective at relaxing credit constraints. We conclude that credit constraints are an important driver of access to programs such as the one we study.

\subsection{Robustness}

We think there are three possible alternative interpretations of our results. The first is that our credit constraints measures capture factors other than credit constraints. The second is that our treatment effect is not driven by relaxation of this constraint, but by income or experimenter demand effects. The third is that behavior reflects households anticipating the option to default on the contract. We address each in turn.

Our credit constraints measures may be capturing some other underlying differences in girls' or households' characteristics. To address this concern, we assess robustness of our estimates to controls. In particular, we estimate specification (2), controlling for baseline covariates and their interaction with Lottery ${ }_{i}$. We include a wide range of covariates capturing education access and attainment (access to tutoring, cognitive skills, distance to school, perceived returns to secondary education), gender attitudes that might affect girls' schooling, preferences (risk aversion and patience), health, household structure. A particular concern is that our measures might simply reflect poverty, so we include measures of per capita expenditures and poverty.

Table 2 presents the results based on the index measure of credit constraints (Appendix Table A.6 uses the binary measure). Each row reports a separate regression. The column entitled "Lottery" displays the estimate of $\beta$ while "Credit" and "Credit $\times$ Lottery' display estimates of $\lambda$ and $\delta$ respectively. "Covariate" and 'Covariate $\times$ Lottery' display coefficients on the covariates we include, and their interaction with Lottery .

The coefficient estimates for $\beta, \lambda$ and $\delta$ are highly robust to controlling for these covariates, both in magnitude and precision. Moreover, the additional covariates and interactions mostly

\footnotetext{
${ }^{15} \mathrm{To}$ aid comparability of effects between columns (3) and (5), we can discretise the index. Notice that $66 \%$ of observations are classified as unconstrained when using the measure of credit constraints in column (3). When constructing a discretised version of the index, we therefore define an observations as credit constrained if its credit constraints index is above the 66th percentile. Using this definition we find that the lottery win itself leads to an increase in the WTP of 104 TSh for unconstrained households, constrained households' WTP is 385 TSh lower, and that the lottery win increases WTP by 446 TSh for constrained households. The coefficients are estimated with less precision.
} 
have small, nonsignificant coefficients. We conclude that the effect of winning the lottery and its differential effects by the credit constraints are unlikely to be driven by omitted variable bias, though of course we cannot rule out the influence of some unobservable factor that is correlated with WTP and credit constraints.

Appendix Table A.5 assesses robustness to alternative specifications. Panel A controls for branch fixed effects. To the extent that the perceived quality of the program varies across the NGO's branches, branch fixed effects capture such differences. Panel B controls for enumerator fixed effects to account for variation in implementation of the WTP meeting. Panel C clusters standard errors at the village level. The findings in Table 1 are robust to these specification changes.

An income effect interpretation of our findings says that winning the lottery increased household wealth, that education is a normal good, and so WTP for the program increased accordingly. In the terminology from the introduction, $V_{i}$ might be increasing in $A_{i}$. We do not have a wealth-preserving credit treatment to fully rule this out, but we can assess its quantitative plausibility. On average, winning the lottery increased WTP by 9\%. The 3,200 TSh prize is around $1.4 \%$ of total household monthly expenditures. Assuming the whole amount is spent within a month, this gives an implied "elasticity" of 6 . Among the constrained group WTP increases $27 \%$, an elasticity of 19 . While we do not have a clear benchmark to compare this to (it is not a traditional income elasticity because the shock is not an income shock and the expenditure is a one-time expense), income effects of this magnitude seem unlikely. ${ }^{16}$

Experimenter demand effects are an alternative explanation. Participants might have perceived that they were expected to increase WTP in response to winning the lottery, and done so out of reciprocity to the study organizers or perceived social pressure. To mitigate these concerns, we framed the lottery ticket as a thank you for participating in the baseline survey, that had already been completed. We explicitly told participants they were "free to do whatever you like with this money," and spent time explaining the study clubs in between the lottery draw and the WTP elicitation. ${ }^{17}$ After our study had been conducted, de Quidt et al. (2018) and Mummolo and Peterson (2018) developed new techniques to measure demand effects, and find they are modest in behavioral experiments conducted online. While the setting is very different, this gives further cause for optimism. Finally, and we think most convincingly, the interaction that we observe between our treatment and the credit constraints measures evades a simple demand effects explanation - it would have to be that

\footnotetext{
${ }^{16}$ We caveat this discussion with the possibility of "house money" or "mental accounting" effects, whereby participants mentally bracket the lottery winnings separately from household finances. Such effects can generate larger income elasticities.

${ }^{17}$ These are consistent with recommended practices in the experimental literature (Zizzo, 2010; de Quidt et al., 2019).
} 
more constrained households are also more responsive in the theoretically predicted direction. We conclude that the credit constraints interpretation is the more plausible one.

Third, while we described the WTP choice as a firm commitment, bound by a "contract," participants might not have viewed it as such. This could cause them to overbid, expecting to have the option to renege later. However, as with the other threats we do not believe this would generate our interaction effect of interest. If anything it could go the other way: limited liability protects households from being forced to pay a bill they cannot afford, so the cash transfer could actually decrease constrained households' propensity to overbid. As described in Section 2.4, due to unanticipated program issues the fees were ultimately not implemented, so we do not know if participants would have honored their commitments. Reviewing the WTP literature, Maffioli et al. (2020) find that non-payment rates are typically in the single digits, though can be much higher in certain cases.

\section{Conclusion}

Despite improvements in access to primary education, learning achievements remain low in many developing countries, particularly for children from lower socio-economic backgrounds. Remedial education programs have emerged as one possible way to ameliorate inequalities in educational attainment.

We study the role of credit constraints in determining families' WTP for a remedial education program offered by an NGO in Tanzania. Through a lottery, we distribute cash prizes that exogenously relax credit constraints for some households. Households are willing to pay $7 \%$ of average monthly per capita expenditure for their daughters to participate in the program. Winning 3,200 TSh in a lottery increases WTP by approximately 9\%. This effect is almost entirely driven by those households our survey identifies as credit constrained, whose WTP is depressed absent the lottery, and who increase their WTP by $27 \%$ when they win the lottery. It is robust to controlling for a host of observable correlates.

We conclude that credit constraints play a significant role in shaping access to educational investment opportunities: households with the ability to borrow value and take up those opportunities; credit constrained households also value them, and in fact value them similarly to unconstrained households, but are not in a position to take up those educational investment opportunities. To the extent that credit constraints are correlated with socio-economic status, these results suggest that they are likely to propagate inequality across generations. 


\section{References}

Abadie, A., S. Athey, G. Imbens, And J. Wooldridge (2017): "When Should You Adjust Standard Errors for Clustering?" NBER Working Paper 24003.

Andersen, S., G. W. HARrison, M. I. LAU, AND E. E. Rutström (2006): “Elicitation using multiple price list formats," Experimental Economics, 9, 383-405.

Angrist, J., E. BetTINGER, AND M. KREMER (2006): “Long-Term Educational Consequences of Secondary School Vouchers: Evidence from Administrative Records in Colombia," American Economic Review, 96, 847-862.

Ashraf, N., J. Berry, AND J. M. Shapiro (2010): “Can Higher Prices Stimulate Product Use? Evidence from a Field Experiment in Zambia," American Economic Review, 100, 2383-2413.

BAird, S., F. H. Ferreira, B. Ozler, AND M. WoOlcock (2014): “Conditional, unconditional and everything in between: a systematic review of the effects of cash transfer programmes on schooling outcomes," Journal of Development Effectiveness, 6, 1-43.

Bandiera, O., N. Buehren, R. Burgess, M. Goldstein, S. Gulesci, I. Rasul, And M. Sulaiman (2020): “Women's Empowerment in Action: Evidence from a Randomized Control Trial in Africa," American Economic Journal: Applied Economics, 12, 210-59.

Banerjee, A., R. BAnerji, J. Berry, E. Duflo, H. Kannan, S. Mukherji, M. Shotland, AND M. WALTON (2016): "Mainstreaming an Effective Intervention: Evidence from Randomized Evaluations of "Teaching at the Right Level" in India," NBER Working Paper 22746.

BAnerJee, A. V., S. Cole, E. Duflo, And L. Linden (2007): “Remedying Education: Evidence from Two Randomized Experiment in India," Quarterly Journal of Economics, 122, 1235-1264.

Banerjee, A. V. AND A. F. Newman (1993): “Occupational Choice and the Process of Development," Journal of Political Economy, 101, 274-298.

Bastagli, F., J. Hagen-Zanker, L. Harman, V. BArCA, G. Sturge, T. Schmidt, And L. Pellerano (2016): "Cash Transfers: What Does the Evidence Say? A Rigorous Review of Impacts and the Role of Design and Implementation Features," Overseas Development Institute Report.

BeAman, L., D. KARLAN, B. Thuysbaert, AND C. UdRY (2015): “Self-selection into Credit Markets: Evidence from Agriculture in Mali," Working paper. 
BeCKer, G. M., M. H. DegroOt, AND J. MARsCHAK (1964): "Measuring utility by a singleresponse sequential method," Behavioral Science, 9, 226-232.

Benhassine, N., F. Devoto, E. Duflo, P. Dupas, And V. Pouliquen (2015): “Turning a Shove into a Nudge? A "Labeled Cash Transfer" for Education," American Economic Journal: Economic Policy, 7, 86-125.

Berkouwer, S. B. And J. T. Dean (2020): “Credit and Attention in the Adoption of Profitable Energy Efficient Technologies in Kenya," Berkeley mimeo.

Berry, J., G. Fischer, AND R. Guiteras (2020): “Eliciting and Utilizing Willingness to Pay: Evidence from Field Trials in Northern Ghana," Journal of Political Economy, 128, 1436-1473.

Berry, J. And P. Mukherjee (2019): “Pricing Private Education in Urban India: Demand, Use, and Impact," Working paper.

Bold, T., M. Kimenyi, G. Mwabu, and J. Sandefur (2014): "Can Free Provision Reduce Demand for Public Services? Evidence from Kenyan Education," The World Bank Economic Review, 29, 293-326.

Burchardi, K., J. DE QuidT, S. Gulesci, B. Lerva, AND S. Tripodi (2021): “Testing Willingness-to-Pay Elicitation Mechanisms in the Field: Evidence from Uganda," CEPR Discussion Paper 15809.

CAmeron, S. V. AND C. TABER (2004): "Estimation of educational borrowing constraints using returns to schooling," Journal of Political Economy, 112, 132-182.

CASABURI, L. AND J. WILlis (2018): “Time versus State in Insurance: Experimental Evidence from Contract Farming in Kenya," American Economic Review, 108, 3778-3813.

Caucutt, E. M. And L. Lochner (2020): “Early and Late Human Capital Investments, Borrowing Constraints, and the Family," Journal of Political Economy, 128, 1065-1147.

Cohen, J. And P. Dupas (2010): “Free Distribution or Cost-sharing? Evidence from a Randomized Malaria Prevention Experiment," Quarterly Journal of Economics, 125, 1-45.

DAHL, G. AND L. LOCHNER (2012): “The impact of family income on child achievement: Evidence from the earned income tax credit," American Economic Review, 102, 1927-56.

DE Mel, S., D. MCKenzie, And C. WoOdruff (2008): "Returns to Capital in Microenterprises: Evidence from a Field Experiment*," The Quarterly Journal of Economics, $123,1329-1372$. 
DE Quidt, J., J. HAushofer, And C. Roth (2018): “Measuring and Bounding Experimenter Demand," American Economic Review, 108, 3266-3302.

DE QuidT, J., L. Vesterlund, AND A. Wilson (2019): “Experimenter demand effects," in Handbook of Research Methods and Applications in Experimental Economics, ed. by A. Schram and A. Ule, Edward Elgar Publishing, 384-400.

DEININGER, K. (2003): “Does cost of schooling affect enrolment by the poor? Universal primary education in Uganda," Economics of Education Review, 22, 291-305.

DupAS, P. (2014): "Short-Run Subsidies and Long-Run Adoption of New Health Products: Evidence From a Field Experiment," Econometrica, 82, 197-228.

Evans, D. K., C. GAlE, AND K. KOSEC (2020): “The Education Impacts of Cash Transfers for Children with Multiple Indicators of Vulnerability," Working paper.

Filmer, D. AND L. PRitchett (1999): “The Effect of Household Wealth on Educational Attainment: Evidence from 35 Countries," Population and Development Review, 25, 85-120.

Fischer, G., D. KARLAN, M. MCCONNELl, AND P. RAFFler (2019): “Short-term subsidies and seller type: A health products experiment in Uganda," Journal of Development Economics, $137,110-124$.

HAushofer, J. AND J. Shapiro (2016): "The Short-term Impact of Unconditional Cash Transfers to the Poor: Experimental Evidence from Kenya," The Quarterly Journal of Economics, 131, 1973-2042.

Heckman, J. J. AND P. CARneiro (2002): "The Evidence on Credit Constraints in Post?Secondary Schooling," Economic Journal, 112, 705-34.

Heckman, J. J. AND S. Mosso (2014): “The Economics of Human Development and Social Mobility," Annual Review of Economics, 6, 210-59.

HoffmanN, V. (2009): “Intrahousehold Allocation of Free and Purchased Mosquito Nets," American Economic Review: Papers E Proceedings, 99, 236-241.

Hoffmann, V., C. B. Barrett, And D. R. Just (2009): “Do Free goods Stick to Poor Households? Experimental Evidence on Insecticide Treated Bednets," World Development, 37, 607-617.

JAYACHANDRAN, S. (2014): "The determinants and impact of private tutoring classes in Vietnam," Journal of Development Economics, 108, 190-205. 
KRemer, M. AND E. Miguel (2007): “The Illusion of Sustainability," Quarterly Journal of Economics, 122, 1007-1065.

Kremer, M., E. Miguel, And R. Thornton (2009): "Incentives to Learn," Review of Economics and Statistics, 91, 437-456.

Maffioli, A., D. MCKenzie, And D. Ubfal (2020): “Estimating the Demand for Business Training: Evidence from Jamaica," World Bank Policy Research Working Paper No. 9415.

MASTERCARD Foundation (2018): “Alternative Education and Return Pathways for Out-ofSchool Youth in Sub-Saharan Africa," https://mastercardfdn.org/wp-content/uploads/ 2019/05/Alternative-Education-and-Return-Pathways-FINAL . pdf.

Montenegro, C. E. And H. A. Patrinos (2014): “Comparable Estimates of Returns to Schooling around the World," Policy Research Working Papers.

Mummolo, J. And E. Peterson (2018): “Demand Effects in Survey Experiments: An Empirical Assessment," American Political Science Review, 113, 517-529.

Muralidharan, K., A. Singh, And A. J. Ganimian (2019): “Disrupting Education? Experimental Evidence on Technology-Aided Instruction in India," American Economic Review, 109, 1426-60.

RiphahN, R. T. (2012): "Effect of Secondary School Fees on Educational Attainment," Scandinavian Journal of Economics, 114, 148-176.

Tarozzi, A., A. Mahajan, B. Blackburn, D. Kopf, L. Krishnan, And J. Yoong (2014): "Micro-loans, Insecticide-Treated Bednets, and Malaria: Evidence from a Randomized Controlled Trial in Orissa, India," American Economic Review, 104, 1909-41.

TDHS (2015-16): Tech. rep., Ministry of Health, Community Development, Gender, Elderly and Children [Tanzania Mainland], Ministry of Health [Zanzibar], National Bureau of Statistics, Office of the Chief Government Statistician, and ICF.

YounG, A. (2019): "Channeling Fisher: Randomization Tests and the Statistical Insignificance of Seemingly Significant Experimental Results," Quarterly Journal of Economics, 134, 557-598.

ZizzO, D. J. (2010): “Experimenter Demand Effects in Economic Experiments," Experimental Economics, 13, 75-98. 


\section{Figures}

Figure 1: Demand Curves

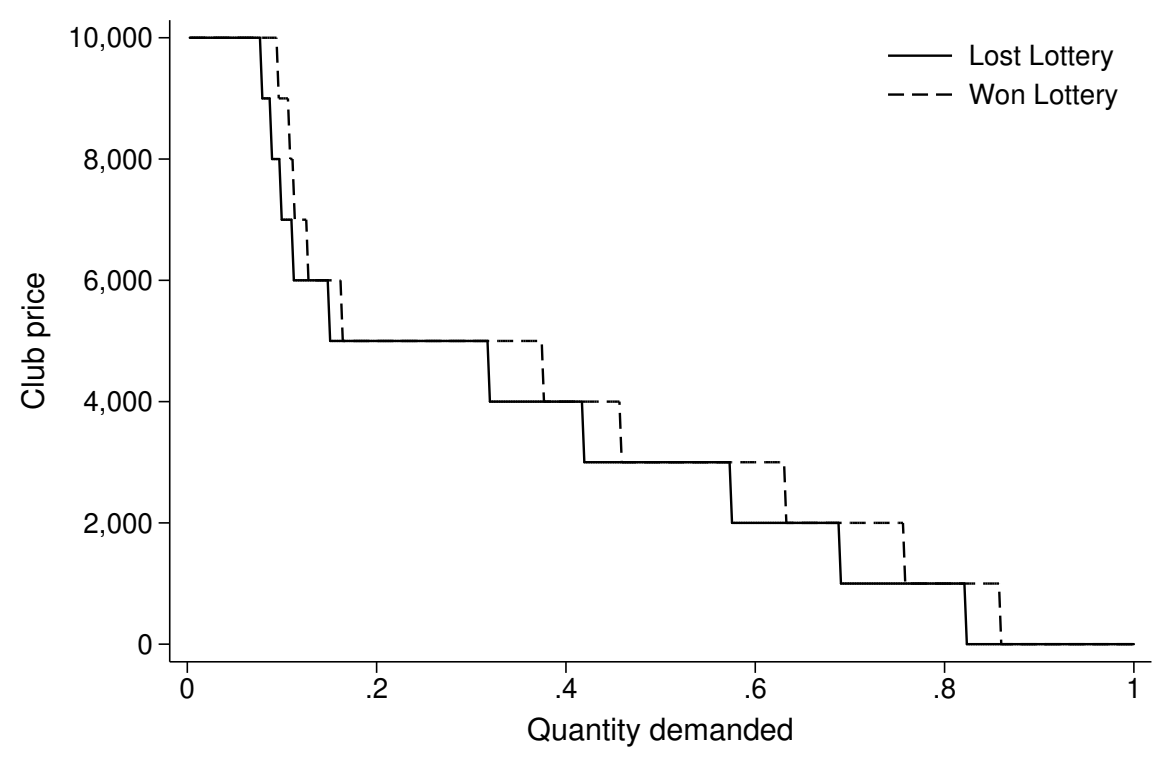

Notes: This figure presents cumulative density functions of households' WTP (in TSh) for the remedial education program, separately for the subsample of households who won the lottery and the subsample who did not win the lottery. The full sample corresponds to the sample used in column 1 of Table 1. 
Figure 2: Demand Curves by CRedit ACcess

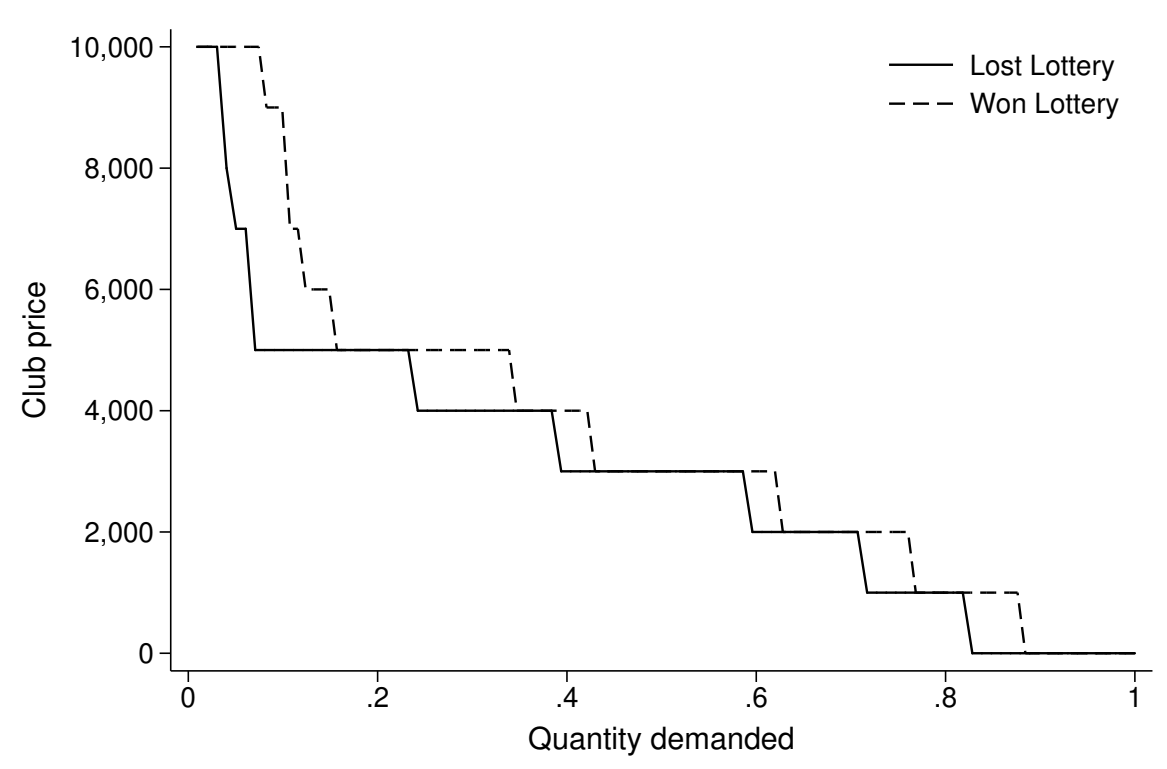

(A) No CREDIT ACCESS

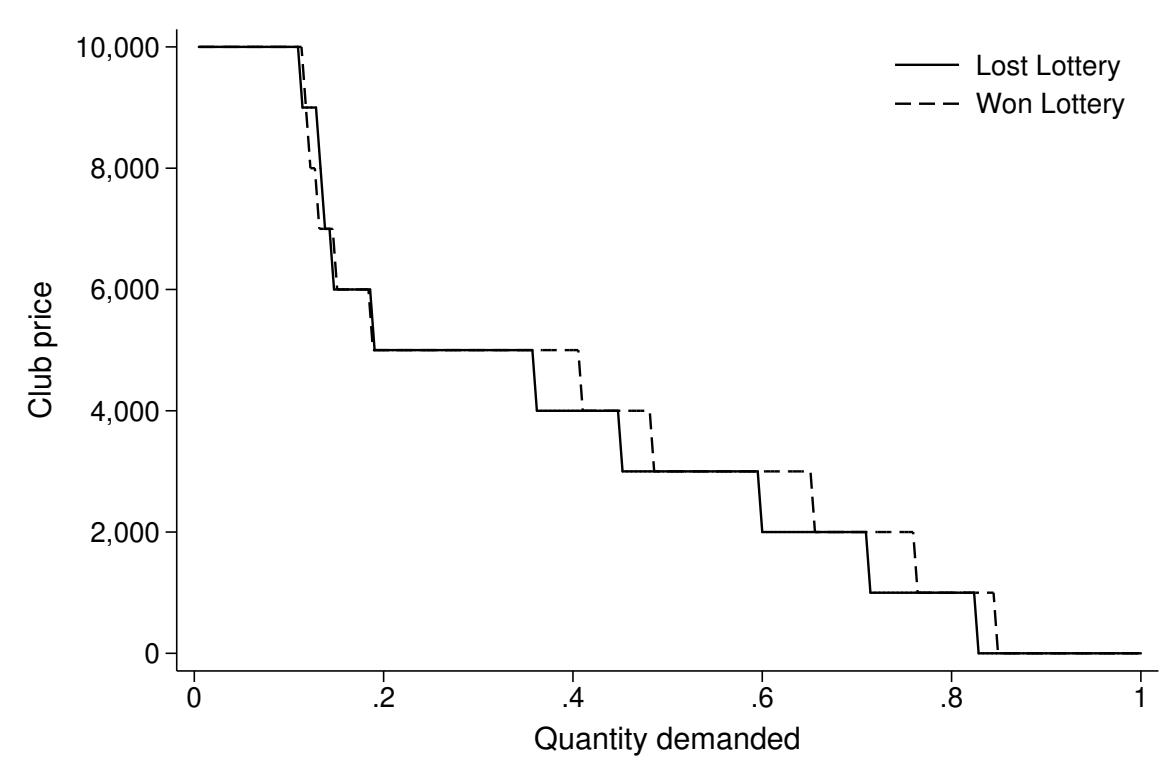

(B) CREDit ACCESS

Notes: These figures present cumulative density functions of households' WTP (in TSh) for the remedial education program, separately for four subgroups: in Figure 2a we present results for the subsample of households whose household head responded that they would not be able to "borrow money for an important expenditure", in Figure 2b we present results for the subsample of households whose household head stated that this would be possible; in both graphs we present results separately for households who won and those who did not win the lottery. The full sample corresponds to the sample used in columns 2 and 3 of Table 1. 


\section{Tables}

TABle 1: Demand For EduCATION AND CRedit Constraints

\begin{tabular}{|c|c|c|c|c|c|}
\hline & \multicolumn{5}{|c|}{ WTP (TSh) } \\
\hline & $(1)$ & $(2)$ & (3) & $(4)$ & (5) \\
\hline Lottery Win & $\begin{array}{l}311 \\
(152) \\
{[0.015]}\end{array}$ & $\begin{array}{l}362 \\
(175) \\
{[0.045]}\end{array}$ & $\begin{array}{l}119 \\
(210) \\
{[0.483]}\end{array}$ & $\begin{array}{l}297 \\
(160) \\
{[0.065]}\end{array}$ & $\begin{array}{l}300 \\
(159) \\
{[0.045]}\end{array}$ \\
\hline No Credit Access & & & $\begin{array}{l}-522 \\
(282) \\
{[0.065]}\end{array}$ & & \\
\hline No Credit Access $\times$ Lottery Win & & & $\begin{array}{l}734 \\
(379) \\
{[0.057]}\end{array}$ & & \\
\hline Credit Constraints Index & & & & & $\begin{array}{l}-399 \\
(129) \\
{[0.002]}\end{array}$ \\
\hline Credit Const. Index $\times$ Lottery Win & & & & & $\begin{array}{l}445 \\
(172) \\
{[0.027]}\end{array}$ \\
\hline Village FE & Yes & Yes & Yes & Yes & Yes \\
\hline Mean Outcome (C) & 3335.0 & 3414.2 & 3414.2 & 3377.8 & 3377.8 \\
\hline Observations & 805 & 642 & 642 & 736 & 736 \\
\hline $\mathrm{R}^{2}$ & 0.474 & 0.493 & 0.497 & 0.482 & 0.490 \\
\hline
\end{tabular}

Notes: The table reports ordinary least squares estimates based on specifications (1) and (2). The dependent variable is the households' WTP (in TSh) for the remedial education program. Lottery Win indicates whether the individual has been randomly assigned to receive a lottery payout. No Credit Access is a dummy variable indicating if the household head reported that it would not be possible for them to borrow money for an important expenditure. Credit Constraints Index is an index combining 4 dummy variables indicating if the respondents (girl or the household head) states that it would not be possible or it would be anything but easy to borrow money for an important expenditure. We calculate the index by first normalizing each indicator by subtracting the sample mean and dividing by its standard deviation; then taking the average of the four normalized indicators, and normalizing again. If only some of these dummies are available we impute the missing ones at the sample mean. All regressions include village fixed effects. Standard errors are clustered at the household level and given in parentheses. In square brackets $p$-values of the null hypothesis of no effect are provided. For the main effect of Lottery Win and interactions with Lottery Win these are calculated as randomization inference $p$-values, for all other coefficients they are calculated analytically based on the reported clustered standard errors. Mean WTP among all lottery losers, and the number of observations, are reported at the bottom of the table. Mean WTP among lottery losers who "can borrow" is 3,633 TSh. Columns 2 and 4 show results from the specification of column 1, but in the samples of columns 3 and 5, respectively. 
TABle 2: Demand For EducAtion And CREDit CONSTRAints IndeX: Robustness to Controls

\begin{tabular}{|c|c|c|c|c|c|c|}
\hline Variable & Lottery & Credit & $\begin{array}{l}\text { Lottery } \\
\times \\
\text { Credit }\end{array}$ & Cova & $\begin{array}{l}\text { eLottery } \\
\times \\
\text { Covar. }\end{array}$ & $\mathrm{N}$ \\
\hline Tutoring & $\begin{array}{l}297 \\
(161) \\
{[0.073]}\end{array}$ & $\begin{array}{l}-399 \\
(126) \\
{[0.002]}\end{array}$ & $\begin{array}{l}421 \\
(168) \\
{[0.010]}\end{array}$ & $\begin{array}{l}-68 \\
(127) \\
{[0.592]}\end{array}$ & $\begin{array}{l}42 \\
(167) \\
{[0.877]}\end{array}$ & 726 \\
\hline Cognitive Skills & $\begin{array}{l}315 \\
(159) \\
{[0.048]}\end{array}$ & $\begin{array}{l}-392 \\
(125) \\
{[0.002]}\end{array}$ & $\begin{array}{l}428 \\
(168) \\
{[0.010]}\end{array}$ & $\begin{array}{l}146 \\
(106) \\
{[0.167]}\end{array}$ & $\begin{array}{l}-186 \\
(158) \\
{[0.294]}\end{array}$ & 736 \\
\hline Distance to School & $\begin{array}{l}312 \\
(159) \\
{[0.052]}\end{array}$ & $\begin{array}{l}-387 \\
(126) \\
{[0.002]}\end{array}$ & $\begin{array}{l}435 \\
(169) \\
{[0.009]}\end{array}$ & $\begin{array}{l}63 \\
(96) \\
{[0.514]}\end{array}$ & $\begin{array}{l}-8 \\
(156) \\
{[0.802]}\end{array}$ & 736 \\
\hline Returns Second. E. & $\begin{array}{l}310 \\
(174) \\
{[0.069]}\end{array}$ & $\begin{array}{l}-445 \\
(128) \\
{[0.001]}\end{array}$ & $\begin{array}{l}492 \\
(177) \\
{[0.004]}\end{array}$ & $\begin{array}{l}281 \\
(129) \\
{[0.030]}\end{array}$ & $\begin{array}{l}-350 \\
(175) \\
{[0.041]}\end{array}$ & 664 \\
\hline Gender Attitude & $\begin{array}{l}284 \\
(162) \\
{[0.084]}\end{array}$ & $\begin{array}{l}-380 \\
(127) \\
{[0.003]}\end{array}$ & $\begin{array}{l}447 \\
(169) \\
{[0.007]}\end{array}$ & $\begin{array}{l}73 \\
(114) \\
{[0.518]}\end{array}$ & $\begin{array}{l}80 \\
(161) \\
{[0.480]}\end{array}$ & 716 \\
\hline Risk Aversion & $\begin{array}{l}307 \\
(165) \\
{[0.067]}\end{array}$ & $\begin{array}{l}-383 \\
(130) \\
{[0.003]}\end{array}$ & $\begin{array}{l}463 \\
(172) \\
{[0.008]}\end{array}$ & $\begin{array}{l}-205 \\
(132) \\
{[0.122]}\end{array}$ & $\begin{array}{l}235 \\
(168) \\
{[0.106]}\end{array}$ & 703 \\
\hline Patience & $\begin{array}{l}281 \\
(171) \\
{[0.096]}\end{array}$ & $\begin{array}{l}-386 \\
(133) \\
{[0.004]}\end{array}$ & $\begin{array}{l}409 \\
(181) \\
{[0.018]}\end{array}$ & $\begin{array}{l}162 \\
(135) \\
{[0.231]}\end{array}$ & $\begin{array}{l}-164 \\
(174) \\
{[0.507]}\end{array}$ & 684 \\
\hline Illness & $\begin{array}{l}307 \\
(161) \\
{[0.059]}\end{array}$ & $\begin{array}{l}-384 \\
(128) \\
{[0.003]}\end{array}$ & $\begin{array}{l}416 \\
(171) \\
{[0.011]}\end{array}$ & $\begin{array}{l}-30 \\
(126) \\
{[0.810]}\end{array}$ & $\begin{array}{l}-69 \\
(163) \\
{[0.520]}\end{array}$ & 727 \\
\hline HH kids (no) & $\begin{array}{l}313 \\
(163) \\
{[0.053]}\end{array}$ & $\begin{array}{l}-403 \\
(126) \\
{[0.001]}\end{array}$ & $\begin{array}{l}455 \\
(168) \\
{[0.008]}\end{array}$ & $\begin{array}{l}-124 \\
(131) \\
{[0.344]}\end{array}$ & $\begin{array}{l}46 \\
(170) \\
{[0.819]}\end{array}$ & 726 \\
\hline HH kids (f/m) & $\begin{array}{l}361 \\
(162) \\
{[0.030]}\end{array}$ & $\begin{array}{l}-412 \\
(127) \\
{[0.001]}\end{array}$ & $\begin{array}{l}500 \\
(168) \\
{[0.004]}\end{array}$ & $\begin{array}{l}75 \\
(121) \\
{[0.533]}\end{array}$ & $\begin{array}{l}-66 \\
(162) \\
{[0.685]}\end{array}$ & 712 \\
\hline Per Capita Expenditure (TSh) & $\begin{array}{l}352 \\
(175) \\
{[0.045]}\end{array}$ & $\begin{array}{l}-412 \\
(133) \\
{[0.002]}\end{array}$ & $\begin{array}{l}439 \\
(178) \\
{[0.014]}\end{array}$ & $\begin{array}{l}-192 \\
(175) \\
{[0.275]}\end{array}$ & $\begin{array}{l}277 \\
(196) \\
{[0.303]}\end{array}$ & 665 \\
\hline Poverty (<2 USD/day) & $\begin{array}{l}352 \\
(175) \\
{[0.045]}\end{array}$ & $\begin{array}{l}-418 \\
(135) \\
{[0.002]}\end{array}$ & $\begin{array}{l}442 \\
(178) \\
{[0.014]}\end{array}$ & $\begin{array}{l}106 \\
(135) \\
{[0.435]}\end{array}$ & $\begin{array}{l}-114 \\
(176) \\
{[0.544]}\end{array}$ & 665 \\
\hline
\end{tabular}

Notes: The table reports ordinary least squares estimates based on specification (2). Lottery indicates whether the individual has been randomly assigned to receive a lottery payout. Credit is an index increasing in credit constraints (see footnote for Table 1 for further details). Tutoring is a dummy variable indicating if the girl attended any tutoring or study group during the past year. Cognitive skills is a normalized index combining the girl's score in a Math exam (EGMA), a reading exam (EGRA) and a Raven's test. Distance to school is the shortest time (in minutes) it takes to reach school. Gender attitude is based on the girl's responses to questions capturing various gender roles in the family (e.g. 'Who should earn money for the family?'). It is the fraction of questions (out of 7) to which the girl responded with gender-neutral roles. Risk Aversion is the girl's response to the question 'On a scale from 0 (not at all willing to take risks) to 10 (very willing to take risks), which number do you give yourself?', inverted. Patience is the girl's response to the question 'On a scale from 0 (very patient) to 10 (very impatient), which number do you give yourself?', inverted. Illness is a dummy variable indicating if the girl reported having had any serious illness in the last year. HH kids (no) is the number of household members younger than 20. HH kids no $(\mathrm{f} / \mathrm{m})$ is the percentage of females among household members younger than 20. Per Capita Expenditure is the monthly household consumption (in Tanzanian Shillings) as reported by the household head, divided by the number of people living in the household. Poverty ( $<2$ USD/day) is a dummy variable indicating if the per capita daily expenditure is less than 2 USD PPP. See Table A.7 in the Online Appendix for further details on the covariates. All regressions include village fixed effects. Standard errors are clustered at the household level and given in parentheses. In square brackets $p$-values of the null hypothesis of no effect are provided. For the main effect of Lottery and interactions with Lottery these are calculated as randomization inference $p$-values, for all other coefficients they are calculated analytically based on the repoted clustered standard errors. 
ONLINE APPENDIX FOR

\title{
CREDIT CONSTRAINTS AND THE DEMAND FOR EDUCATION: EVIDENCE FROM TANZANIA
}

\author{
Konrad Burchardi, Jonathan de Quidt, Selim Gulesci, Munshi Sulaiman
}

\section{A Appendix Tables}

TABle A.1: SElection of MARginalized SAMPle

\begin{tabular}{|c|c|c|c|c|c|}
\hline & (1) & $(2)$ & (3) & (4) & (5) \\
\hline & \multicolumn{2}{|c|}{ Census } & \multirow[b]{2}{*}{ Difference } & \multirow[b]{2}{*}{ Norm. D. } & \multirow[b]{2}{*}{$\mathrm{N}$} \\
\hline & All & Marginal. & & & \\
\hline \# Girls in household & $\begin{array}{l}1.394 \\
(0.738)\end{array}$ & $\begin{array}{l}1.420 \\
(0.769)\end{array}$ & $\begin{array}{l}0.168^{* * *} \\
{[0.000]}\end{array}$ & 0.257 & $5965 / 5045$ \\
\hline \# Household members & $\begin{array}{l}8.778 \\
(8.183)\end{array}$ & $\begin{array}{l}8.590 \\
(8.174)\end{array}$ & $\begin{array}{l}-1.219^{* * *} \\
{[0.000]}\end{array}$ & -0.149 & $5965 / 5046$ \\
\hline All children aged 6-17 in school & $\begin{array}{l}2.244 \\
(1.439)\end{array}$ & $\begin{array}{l}2.170 \\
(1.460)\end{array}$ & $\begin{array}{l}-0.477^{* * *} \\
{[0.000]}\end{array}$ & -0.352 & $5961 / 5044$ \\
\hline Female head/spouse is literate & $\begin{array}{l}0.913 \\
(0.281)\end{array}$ & $\begin{array}{l}0.901 \\
(0.298)\end{array}$ & $\begin{array}{l}-0.078^{* * *} \\
{[0.000]}\end{array}$ & -0.334 & $5968 / 5048$ \\
\hline Concrete/tiled/timbered floor & $\begin{array}{l}0.753 \\
(0.431)\end{array}$ & $\begin{array}{l}0.719 \\
(0.449)\end{array}$ & $\begin{array}{l}-0.220^{* * *} \\
{[0.000]}\end{array}$ & -0.611 & $5968 / 5048$ \\
\hline Metal/tiled roof & $\begin{array}{l}0.910 \\
(0.286)\end{array}$ & $\begin{array}{l}0.904 \\
(0.295)\end{array}$ & $\begin{array}{l}-0.042^{* * *} \\
{[0.000]}\end{array}$ & -0.159 & $5968 / 5048$ \\
\hline HH owns bicycles/vehicles & $\begin{array}{l}0.171 \\
(0.376)\end{array}$ & $\begin{array}{l}0.135 \\
(0.342)\end{array}$ & $\begin{array}{l}-0.229^{* * *} \\
{[0.000]}\end{array}$ & -0.548 & $5968 / 5048$ \\
\hline HH owns radio & $\begin{array}{l}0.618 \\
(0.486)\end{array}$ & $\begin{array}{l}0.569 \\
(0.495)\end{array}$ & $\begin{array}{l}-0.320^{* * *} \\
{[0.000]}\end{array}$ & -0.772 & $5968 / 5048$ \\
\hline HH owns lantern & $\begin{array}{l}0.482 \\
(0.500)\end{array}$ & $\begin{array}{l}0.450 \\
(0.498)\end{array}$ & $\begin{array}{l}-0.206^{* * *} \\
{[0.000]}\end{array}$ & -0.424 & $5968 / 5048$ \\
\hline HH owns iron & $\begin{array}{l}0.545 \\
(0.498)\end{array}$ & $\begin{array}{l}0.488 \\
(0.500)\end{array}$ & $\begin{array}{l}-0.368^{* * *} \\
{[0.000]}\end{array}$ & -0.853 & $5968 / 5048$ \\
\hline \# Tables HH owns & $\begin{array}{l}0.830 \\
(0.375)\end{array}$ & $\begin{array}{l}0.810 \\
(0.393)\end{array}$ & $\begin{array}{l}-0.134^{* * *} \\
{[0.000]}\end{array}$ & -0.416 & $5968 / 5048$ \\
\hline
\end{tabular}

Notes: The table presents summary statistics for a number of census variables within the sample of census girls in the 69 study villages (in Column 1) and the narrower sample of girls who are marginalized (in Column 2). The mean and standard deviation (in parentheses) of the covariate in each respective sample are shown. We run a regression of the outcome on an indicator of being a member of the sample of Column 2. The coefficient estimate on the indicator is provided in Column 3 , and associated $p$-values testing the null of no difference, based on standard errors clustered at the household level, are provided in square brackets. In Column 4 the normalized difference between the samples in Column 1 and 2 is given. In Column 5 the size of the sample of Column 1 and Column 2 are shown. 


\begin{tabular}{llllll}
\hline & $(1)$ & $(2)$ & $(3)$ & $(4)$ & $(5)$ \\
& $\begin{array}{l}\text { Census: } \\
\text { Marginal. }\end{array}$ & Baseline & Difference & Norm. D. & $\mathrm{N}$ \\
& & & & \\
\hline \# Girls in household & 1.420 & 1.354 & $-0.096^{* * *}$ & -0.130 & $5045 / 1579$ \\
& $(0.769)$ & $(0.654)$ & {$[0.000]$} & & \\
\# Household members & 8.590 & 8.805 & 0.313 & 0.038 & $5046 / 1580$ \\
& $(8.174)$ & $(8.289)$ & {$[0.223]$} & & \\
All children aged 6-17 in school & 2.170 & 2.217 & 0.068 & 0.046 & $5044 / 1579$ \\
& $(1.460)$ & $(1.602)$ & {$[0.153]$} & & \\
Female head/spouse is literate & 0.901 & 0.887 & $-0.020^{* *}$ & -0.067 & $5048 / 1581$ \\
& $(0.298)$ & $(0.316)$ & {$[0.036]$} & & \\
Concrete/tiled/timbered floor & 0.719 & 0.682 & $-0.055^{* * *}$ & -0.120 & $5048 / 1581$ \\
& $(0.449)$ & $(0.466)$ & {$[0.000]$} & & \\
Metal/tiled roof & 0.904 & 0.918 & $0.020^{* *}$ & 0.070 & $5048 / 1581$ \\
& $(0.295)$ & $(0.275)$ & {$[0.020]$} & & \\
HH owns bicycles/vehicles & 0.135 & 0.167 & $0.046^{* * *}$ & 0.132 & $5048 / 1581$ \\
& $(0.342)$ & $(0.373)$ & {$[0.000]$} & & \\
HH owns radio & 0.569 & 0.533 & $-0.053^{* * *}$ & -0.107 & $5048 / 1581$ \\
& $(0.495)$ & $(0.499)$ & {$[0.001]$} & & \\
HH owns lantern & 0.450 & 0.469 & $0.028^{*}$ & 0.056 & $5048 / 1581$ \\
& $(0.498)$ & $(0.499)$ & {$[0.075]$} & & \\
HH owns iron & 0.488 & 0.460 & $-0.041^{* * *}$ & -0.083 & $5048 / 1581$ \\
& $(0.500)$ & $(0.499)$ & {$[0.008]$} & & \\
\# Tables HH owns & 0.810 & 0.755 & $-0.080^{* * *}$ & -0.199 & $5048 / 1581$ \\
& $(0.393)$ & $(0.430)$ & {$[0.000]$} & & \\
\hline
\end{tabular}

Notes: The table presents summary statistics for a number of census variables within the sample of marginalized census girls in the 69 study villages (in Column 1) and the narrower sample for whom additionally a baseline was conducted (in Column 2). The mean and standard deviation (in parentheses) of the covariate in each respective sample are shown. We run a regression of the outcome on an indicator of being a member of the sample of Column 2. The coefficient estimate on the indicator is provided in Column 3, and associated $p$-values testing the null of no difference, based on standard errors clustered at the household level, are provided in square brackets. In Column 4 the normalized difference between the samples in Column 1 and 2 is given. In Column 5 the size of the sample of Column 1 and Column 2 are shown. 


\begin{tabular}{|c|c|c|c|c|c|}
\hline & $\begin{array}{l}(1) \\
\text { Baseline }\end{array}$ & $\begin{array}{l}(2) \\
\text { WTP }\end{array}$ & $\begin{array}{l}(3) \\
\text { Difference }\end{array}$ & $\begin{array}{l}(4) \\
\text { Norm. D. }\end{array}$ & $\begin{array}{l}(5) \\
\mathrm{N}\end{array}$ \\
\hline EGRA (word / min) & $\begin{array}{l}40.90 \\
(36.94)\end{array}$ & $\begin{array}{l}42.73 \\
(46.72)\end{array}$ & $\begin{array}{l}3.89^{*} \\
{[0.069]}\end{array}$ & 0.099 & $1428 / 711$ \\
\hline EGMA & $\begin{array}{l}0.615 \\
(0.137)\end{array}$ & $\begin{array}{l}0.613 \\
(0.133)\end{array}$ & $\begin{array}{l}0.002 \\
{[0.791]}\end{array}$ & -0.033 & $1531 / 757$ \\
\hline Raven Score & $\begin{array}{l}3.567 \\
(1.715)\end{array}$ & $\begin{array}{l}3.579 \\
(1.724)\end{array}$ & $\begin{array}{l}0.087 \\
{[0.311]}\end{array}$ & 0.014 & $1631 / 805$ \\
\hline Girl: No Credit Access & $\begin{array}{l}0.677 \\
(0.468)\end{array}$ & $\begin{array}{l}0.689 \\
(0.463)\end{array}$ & $\begin{array}{l}-0.000 \\
{[0.985]}\end{array}$ & 0.047 & $1178 / 578$ \\
\hline Girl: No Easy Credit Access & $\begin{array}{l}0.927 \\
(0.260)\end{array}$ & $\begin{array}{l}0.936 \\
(0.245)\end{array}$ & $\begin{array}{l}0.007 \\
{[0.643]}\end{array}$ & 0.068 & $1178 / 578$ \\
\hline HH: No Credit Access & $\begin{array}{l}0.342 \\
(0.474)\end{array}$ & $\begin{array}{l}0.343 \\
(0.475)\end{array}$ & $\begin{array}{l}-0.019 \\
{[0.453]}\end{array}$ & 0.004 & $1276 / 642$ \\
\hline HH: No Easy Credit Access & $\begin{array}{l}0.813 \\
(0.390)\end{array}$ & $\begin{array}{l}0.824 \\
(0.381)\end{array}$ & $\begin{array}{l}-0.006 \\
{[0.785]}\end{array}$ & 0.054 & $1276 / 642$ \\
\hline Per Capita Expenditure (TSh) & $\begin{array}{l}45193 \\
(68651)\end{array}$ & $\begin{array}{l}48077 \\
(78894)\end{array}$ & $\begin{array}{l}4389 \\
{[0.255]}\end{array}$ & 0.084 & $1418 / 710$ \\
\hline Tutoring & $\begin{array}{l}0.596 \\
(0.491)\end{array}$ & $\begin{array}{l}0.599 \\
(0.490)\end{array}$ & $\begin{array}{l}0.008 \\
{[0.737]}\end{array}$ & 0.015 & $1608 / 789$ \\
\hline Cognitive Skills & $\begin{array}{l}-0.000 \\
(1.000)\end{array}$ & $\begin{array}{l}0.020 \\
(1.049)\end{array}$ & $\begin{array}{l}0.091^{*} \\
{[0.086]}\end{array}$ & 0.038 & $1631 / 805$ \\
\hline Distance to School & $\begin{array}{l}23.34 \\
(22.53)\end{array}$ & $\begin{array}{l}23.83 \\
(23.49)\end{array}$ & $\begin{array}{l}0.79 \\
{[0.505]}\end{array}$ & 0.043 & $1631 / 805$ \\
\hline Returns Second. E. & $\begin{array}{l}0.216 \\
(0.412)\end{array}$ & $\begin{array}{l}0.209 \\
(0.407)\end{array}$ & $\begin{array}{l}-0.001 \\
{[0.948]}\end{array}$ & -0.033 & $1492 / 723$ \\
\hline Gender Attitude & $\begin{array}{l}0.323 \\
(0.266)\end{array}$ & $\begin{array}{l}0.311 \\
(0.270)\end{array}$ & $\begin{array}{l}-0.020 \\
{[0.108]}\end{array}$ & -0.087 & $1587 / 775$ \\
\hline Risk Aversion & $\begin{array}{l}3.324 \\
(3.573)\end{array}$ & $\begin{array}{l}3.177 \\
(3.579)\end{array}$ & $\begin{array}{l}-0.050 \\
{[0.751]}\end{array}$ & -0.081 & $1552 / 761$ \\
\hline Patience & $\begin{array}{l}5.324 \\
(3.890)\end{array}$ & $\begin{array}{l}5.077 \\
(3.998)\end{array}$ & $\begin{array}{l}-0.307^{*} \\
{[0.060]}\end{array}$ & -0.124 & $1520 / 742$ \\
\hline Illness & $\begin{array}{l}0.520 \\
(0.500)\end{array}$ & $\begin{array}{l}0.514 \\
(0.500)\end{array}$ & $\begin{array}{l}0.001 \\
{[0.962]}\end{array}$ & -0.025 & $1597 / 790$ \\
\hline HH kids (no) & $\begin{array}{l}3.004 \\
(1.662)\end{array}$ & $\begin{array}{l}3.080 \\
(1.644)\end{array}$ & $\begin{array}{l}0.171^{* *} \\
{[0.036]}\end{array}$ & 0.090 & $1586 / 784$ \\
\hline HH kids (f/m) & $\begin{array}{l}73.59 \\
(27.55)\end{array}$ & $\begin{array}{l}73.76 \\
(27.35)\end{array}$ & $\begin{array}{l}0.17 \\
{[0.909]}\end{array}$ & 0.012 & $1547 / 769$ \\
\hline
\end{tabular}

Notes: The table presents summary statistics for a number of covariates within the sample of successfully interviewed baseline girls in the 65 villages where a lottery was conducted (in Column 1) and the narrower sample for whom additionally their WTP was elicited (in Column 2). The sample of Column 2 corresponds to the estimation sample of Table 1. The mean and standard deviation (in parentheses) of the covariate in each respective sample are shown. We run a regression of the outcome on an indicator of being a member of the sample of Column 2 as well as village fixed effects. The coefficient estimate on the indicator is provided in Column 3 , and associated $p$-values testing the null of no difference, based on standard errors clustered at the household level, are provided in square brackets. In Column 4 the normalized difference between the samples in Column 1 and 2 is given. In Column 5 the size of the sample of Column 1 and Column 2 are shown. 


\begin{tabular}{|c|c|c|c|c|c|}
\hline & $\begin{array}{l}(1) \\
\text { Control }\end{array}$ & $\begin{array}{l}(2) \\
\text { Lottery } \\
\text { Win }\end{array}$ & $\begin{array}{l}(3) \\
\text { Difference }\end{array}$ & $\begin{array}{l}(4) \\
\text { Norm. D. }\end{array}$ & $\begin{array}{l}(5) \\
\mathrm{N}\end{array}$ \\
\hline EGRA (word / min) & $\begin{array}{l}42.57 \\
(38.44)\end{array}$ & $\begin{array}{l}42.88 \\
(53.39)\end{array}$ & $\begin{array}{l}0.98 \\
{[0.804]}\end{array}$ & 0.007 & $344 / 367$ \\
\hline EGMA & $\begin{array}{l}0.609 \\
(0.136)\end{array}$ & $\begin{array}{l}0.616 \\
(0.130)\end{array}$ & $\begin{array}{l}0.006 \\
{[0.543]}\end{array}$ & 0.055 & $366 / 391$ \\
\hline Raven Score & $\begin{array}{l}3.701 \\
(1.675)\end{array}$ & $\begin{array}{l}3.464 \\
(1.764)\end{array}$ & $\begin{array}{l}-0.223^{*} \\
{[0.052]}\end{array}$ & -0.138 & $391 / 414$ \\
\hline Girl: No Credit Access & $\begin{array}{l}0.671 \\
(0.471)\end{array}$ & $\begin{array}{l}0.705 \\
(0.457)\end{array}$ & $\begin{array}{l}0.063^{*} \\
{[0.066]}\end{array}$ & 0.073 & $283 / 295$ \\
\hline Girl: No Easy Credit Access & $\begin{array}{l}0.933 \\
(0.251)\end{array}$ & $\begin{array}{l}0.939 \\
(0.240)\end{array}$ & $\begin{array}{l}0.020 \\
{[0.312]}\end{array}$ & 0.025 & $283 / 295$ \\
\hline HH: No Credit Access & $\begin{array}{l}0.320 \\
(0.467)\end{array}$ & $\begin{array}{l}0.363 \\
(0.482)\end{array}$ & $\begin{array}{l}0.034 \\
{[0.344]}\end{array}$ & 0.091 & $309 / 333$ \\
\hline HH: No Easy Credit Access & $\begin{array}{l}0.825 \\
(0.380)\end{array}$ & $\begin{array}{l}0.823 \\
(0.382)\end{array}$ & $\begin{array}{l}0.003 \\
{[0.909]}\end{array}$ & -0.006 & $309 / 333$ \\
\hline Credit Constraint Index & $\begin{array}{l}-0.037 \\
(0.967)\end{array}$ & $\begin{array}{l}0.036 \\
(1.031)\end{array}$ & $\begin{array}{l}0.092 \\
{[0.175]}\end{array}$ & 0.073 & $360 / 376$ \\
\hline Per Capita Expenditure (TSh) & $\begin{array}{l}46948 \\
(60523)\end{array}$ & $\begin{array}{l}49103 \\
(92550)\end{array}$ & $\begin{array}{l}1213 \\
{[0.815]}\end{array}$ & 0.028 & $338 / 372$ \\
\hline Tutoring & $\begin{array}{l}0.606 \\
(0.489)\end{array}$ & $\begin{array}{l}0.594 \\
(0.492)\end{array}$ & $\begin{array}{l}-0.006 \\
{[0.851]}\end{array}$ & -0.025 & $383 / 406$ \\
\hline Cognitive Skills & $\begin{array}{l}0.043 \\
(1.007)\end{array}$ & $\begin{array}{l}-0.002 \\
(1.089)\end{array}$ & $\begin{array}{l}-0.034 \\
{[0.658]}\end{array}$ & -0.043 & $391 / 414$ \\
\hline Distance to School & $\begin{array}{l}23.86 \\
(24.10)\end{array}$ & $\begin{array}{l}23.80 \\
(22.93)\end{array}$ & $\begin{array}{l}-0.04 \\
{[0.979]}\end{array}$ & -0.002 & $391 / 414$ \\
\hline Returns Second. E. & $\begin{array}{l}0.214 \\
(0.411)\end{array}$ & $\begin{array}{l}0.204 \\
(0.403)\end{array}$ & $\begin{array}{l}-0.013 \\
{[0.669]}\end{array}$ & -0.026 & $350 / 373$ \\
\hline Gender Attitude & $\begin{array}{l}0.308 \\
(0.275)\end{array}$ & $\begin{array}{l}0.314 \\
(0.266)\end{array}$ & $\begin{array}{l}0.010 \\
{[0.565]}\end{array}$ & 0.021 & $377 / 398$ \\
\hline Risk Aversion & $\begin{array}{l}3.054 \\
(3.528)\end{array}$ & $\begin{array}{l}3.293 \\
(3.628)\end{array}$ & $\begin{array}{l}0.149 \\
{[0.498]}\end{array}$ & 0.067 & $368 / 393$ \\
\hline Patience & $\begin{array}{l}5.180 \\
(4.060)\end{array}$ & $\begin{array}{l}4.982 \\
(3.944)\end{array}$ & $\begin{array}{l}-0.043 \\
{[0.855]}\end{array}$ & -0.050 & $355 / 387$ \\
\hline Illness & $\begin{array}{l}0.494 \\
(0.501)\end{array}$ & $\begin{array}{l}0.533 \\
(0.500)\end{array}$ & $\begin{array}{l}0.037 \\
{[0.266]}\end{array}$ & 0.080 & $385 / 405$ \\
\hline HH kids (no) & $\begin{array}{l}3.180 \\
(1.617)\end{array}$ & $\begin{array}{l}2.988 \\
(1.665)\end{array}$ & $\begin{array}{l}-0.196^{*} \\
{[0.068]}\end{array}$ & -0.117 & $378 / 406$ \\
\hline HH kids (f/m) & $\begin{array}{l}73.78 \\
(26.07)\end{array}$ & $\begin{array}{l}73.74 \\
(28.53)\end{array}$ & $\begin{array}{l}-0.04 \\
{[0.984]}\end{array}$ & -0.001 & $373 / 396$ \\
\hline
\end{tabular}

Notes: The table presents summary statistics for a number of covariates for the estimation sample of Table 1, i.e. the sample of girls who have both been interviewed at baseline and a WTP has been elicited. The mean and standard deviation (in parentheses) of the covariate in the sample of girls who won the lottery (Column 2) and who did not win the lottery (Column 1) are provided. To test for differences between those samples along the covariates, we run an ordinary least squares regression of specification (1), i.e. including village fixed effects, with the covariate as dependent variable. The coefficient estimate on Lottery Win is provided in Column 3 , and associated $p$-values testing the null of no difference, based on standard errors clustered at the household level, are provided in square brackets. In Column 4 the normalized difference between the samples in Column 1 and 2 is given. In Column 5 the size of the samples of Column 1 and Column 2 are shown. 


\begin{tabular}{|c|c|c|c|c|c|}
\hline & \multicolumn{5}{|c|}{ WTP (TSh) } \\
\hline & $(1)$ & $(2)$ & (3) & $(4)$ & (5) \\
\hline \multicolumn{6}{|l|}{ Panel A: Branch Fixed Effects } \\
\hline Lottery Win & $\begin{array}{l}332 \\
(171) \\
{[0.060]}\end{array}$ & $\begin{array}{l}359 \\
(192) \\
{[0.081]}\end{array}$ & $\begin{array}{l}203 \\
(240) \\
{[0.595]}\end{array}$ & $\begin{array}{l}334 \\
(178) \\
{[0.071]}\end{array}$ & $\begin{array}{l}355 \\
(176) \\
{[0.052]}\end{array}$ \\
\hline No Credit Access & & & $\begin{array}{l}-739 \\
(295) \\
{[0.012]}\end{array}$ & & \\
\hline No Credit Access $\times$ Lottery Win & & & $\begin{array}{l}514 \\
(400) \\
{[0.131]}\end{array}$ & & \\
\hline Credit Constraints Index & & & & & $\begin{array}{l}-519 \\
(133) \\
{[0.000]}\end{array}$ \\
\hline Credit Const. Index $\times$ Lottery Win & & & & & $\begin{array}{l}473 \\
(178) \\
{[0.006]}\end{array}$ \\
\hline Branch FE & Yes & Yes & Yes & Yes & Yes \\
\hline $\mathrm{R}^{2}$ & 0.276 & 0.293 & 0.300 & 0.282 & 0.297 \\
\hline \multicolumn{6}{|l|}{ Panel B: Enumerator Fixed Effects } \\
\hline Lottery Win & $\begin{array}{l}344 \\
(167) \\
{[0.051]}\end{array}$ & $\begin{array}{l}380 \\
(189) \\
{[0.059]}\end{array}$ & $\begin{array}{l}240 \\
(234) \\
{[0.447]}\end{array}$ & $\begin{array}{l}349 \\
(174) \\
{[0.058]}\end{array}$ & $\begin{array}{l}369 \\
(172) \\
{[0.045]}\end{array}$ \\
\hline No Credit Access & & & $\begin{array}{l}-619 \\
(290) \\
{[0.033]}\end{array}$ & & \\
\hline No Credit Access $\times$ Lottery Win & & & $\begin{array}{l}455 \\
(391) \\
{[0.186]}\end{array}$ & & \\
\hline Credit Constraints Index & & & & & $\begin{array}{l}-488 \\
(126) \\
{[0.000]}\end{array}$ \\
\hline Credit Const. Index × Lottery Win & & & & & $\begin{array}{l}435 \\
(172) \\
{[0.012]}\end{array}$ \\
\hline Enumerator FE & Yes & Yes & Yes & Yes & Yes \\
\hline $\mathrm{R}^{2}$ & 0.305 & 0.321 & 0.326 & 0.314 & 0.327 \\
\hline \multicolumn{6}{|c|}{ Panel C: Standard Errors Clustered at Village Level } \\
\hline Lottery Win & $\begin{array}{l}311 \\
(206) \\
{[0.038]}\end{array}$ & $\begin{array}{l}362 \\
(223) \\
{[0.040]}\end{array}$ & $\begin{array}{l}119 \\
(257) \\
{[0.602]}\end{array}$ & $\begin{array}{l}297 \\
(211) \\
{[0.065]}\end{array}$ & $\begin{array}{l}312 \\
(201) \\
{[0.051]}\end{array}$ \\
\hline No Credit Access & & & $\begin{array}{l}-522 \\
(309) \\
{[0.096]}\end{array}$ & & \\
\hline No Credit Access $\times$ Lottery Win & & & $\begin{array}{l}734 \\
(425) \\
{[0.051]}\end{array}$ & & \\
\hline Credit Constraints Index & & & & & $\begin{array}{l}-387 \\
(137) \\
{[0.006]}\end{array}$ \\
\hline Credit Const. Index $\times$ Lottery Win & & & & & $\begin{array}{l}432 \\
(206) \\
{[0.009]}\end{array}$ \\
\hline Village FE & Yes & Yes & Yes & Yes & Yes \\
\hline $\mathrm{R}^{2}$ & 0.474 & 0.493 & 0.497 & 0.482 & 0.490 \\
\hline
\end{tabular}

Notes: The table reports ordinary least squares estimates based on specifications (1) and (2). Lottery indicates whether the individual has been randomly assigned to receive a lottery payout. Credit indicates whether the household head responded that she/he would not be able to "borrow money for an important expenditure". Credit Constraints Index is an index over 4 variables measuring the extent of credit constraints. Standard errors are given in parentheses. In square brackets $p$-values of the null hypothesis of no effect are provided. For the main effect of Lottery Win and interactions with Lottery Win these are calculated as randomization inference $p$-values, for all other coefficients they are calculated analytically based on the reported clustered standard errors. Columns 2 and 4 show results from the specification of column 1, but in the samples of columns 3 and 5, respectively. Each panel presents a variation of the specifications underlying the results of Table 1: In Panel A and B branch and enumerator fixed effects are included instead of village fixed effects, respectively. In Panel C standard errors are clustered at the village level instead of the household level. 


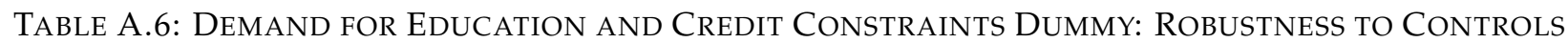

\begin{tabular}{|c|c|c|c|c|c|c|}
\hline Variable & Lottery & Credit & $\begin{array}{l}\text { Lottery } \\
\times \\
\text { Credit }\end{array}$ & Cova & $\begin{array}{l}\text { eLottery } \\
\times \\
\text { Covar. }\end{array}$ & $\mathrm{N}$ \\
\hline Tutoring & $\begin{array}{l}108 \\
(213) \\
{[0.646]}\end{array}$ & $\begin{array}{l}-545 \\
(285) \\
{[0.056]}\end{array}$ & $\begin{array}{l}719 \\
(381) \\
{[0.062]}\end{array}$ & $\begin{array}{l}-137 \\
(139) \\
{[0.324]}\end{array}$ & $\begin{array}{l}184 \\
(181) \\
{[0.334]}\end{array}$ & 633 \\
\hline Cognitive Skills & $\begin{array}{l}129 \\
(209) \\
{[0.568]}\end{array}$ & $\begin{array}{l}-517 \\
(283) \\
{[0.068]}\end{array}$ & $\begin{array}{l}720 \\
(379) \\
{[0.057]}\end{array}$ & $\begin{array}{l}96 \\
(121) \\
{[0.428]}\end{array}$ & $\begin{array}{l}-129 \\
(181) \\
{[0.496]}\end{array}$ & 642 \\
\hline Distance to School & $\begin{array}{l}124 \\
(210) \\
{[0.585]}\end{array}$ & $\begin{array}{l}-511 \\
(283) \\
{[0.071]}\end{array}$ & $\begin{array}{l}725 \\
(379) \\
{[0.056]}\end{array}$ & $\begin{array}{l}130 \\
(100) \\
{[0.196]}\end{array}$ & $\begin{array}{l}-104 \\
(176) \\
{[0.452]}\end{array}$ & 642 \\
\hline Returns Second. E. & $\begin{array}{l}91 \\
(228) \\
{[0.741]}\end{array}$ & $\begin{array}{l}-609 \\
(301) \\
{[0.044]}\end{array}$ & $\begin{array}{l}866 \\
(413) \\
{[0.033]}\end{array}$ & $\begin{array}{l}370 \\
(144) \\
{[0.010]}\end{array}$ & $\begin{array}{l}-441 \\
(201) \\
{[0.019]}\end{array}$ & 577 \\
\hline Gender Attitude & $\begin{array}{l}81 \\
(215) \\
{[0.754]}\end{array}$ & $\begin{array}{l}-483 \\
(285) \\
{[0.091]}\end{array}$ & $\begin{array}{l}781 \\
(386) \\
{[0.044]}\end{array}$ & $\begin{array}{l}7 \\
(128) \\
{[0.955]}\end{array}$ & $\begin{array}{l}191 \\
(183) \\
{[0.211]}\end{array}$ & 624 \\
\hline Risk Aversion & $\begin{array}{l}77 \\
(219) \\
{[0.748]}\end{array}$ & $\begin{array}{l}-498 \\
(293) \\
{[0.090]}\end{array}$ & $\begin{array}{l}819 \\
(396) \\
{[0.038]}\end{array}$ & $\begin{array}{l}-159 \\
(143) \\
{[0.267]}\end{array}$ & $\begin{array}{l}135 \\
(186) \\
{[0.312]}\end{array}$ & 613 \\
\hline Patience & $\begin{array}{l}84 \\
(223) \\
{[0.766]}\end{array}$ & $\begin{array}{l}-520 \\
(309) \\
{[0.092]}\end{array}$ & $\begin{array}{l}762 \\
(416) \\
{[0.055]}\end{array}$ & $\begin{array}{l}73 \\
(151) \\
{[0.628]}\end{array}$ & $\begin{array}{l}-37 \\
(190) \\
{[0.903]}\end{array}$ & 600 \\
\hline Illness & $\begin{array}{l}115 \\
(212) \\
{[0.621]}\end{array}$ & $\begin{array}{l}-528 \\
(284) \\
{[0.064]}\end{array}$ & $\begin{array}{l}708 \\
(383) \\
{[0.063]}\end{array}$ & $\begin{array}{l}56 \\
(139) \\
{[0.689]}\end{array}$ & $\begin{array}{l}-74 \\
(175) \\
{[0.496]}\end{array}$ & 635 \\
\hline HH kids (no) & $\begin{array}{l}95 \\
(213) \\
{[0.698]}\end{array}$ & $\begin{array}{l}-545 \\
(279) \\
{[0.051]}\end{array}$ & $\begin{array}{l}765 \\
(377) \\
{[0.045]}\end{array}$ & $\begin{array}{l}-143 \\
(144) \\
{[0.322]}\end{array}$ & $\begin{array}{l}69 \\
(188) \\
{[0.717]}\end{array}$ & 640 \\
\hline HH kids (f/m) & $\begin{array}{l}126 \\
(213) \\
{[0.585]}\end{array}$ & $\begin{array}{l}-547 \\
(280) \\
{[0.052]}\end{array}$ & $\begin{array}{l}851 \\
(380) \\
{[0.023]}\end{array}$ & $\begin{array}{l}14 \\
(136) \\
{[0.919]}\end{array}$ & $\begin{array}{l}-0 \\
(179) \\
{[0.999]}\end{array}$ & 632 \\
\hline Per Capita Expenditure (TSh) & $\begin{array}{l}166 \\
(216) \\
{[0.463]}\end{array}$ & $\begin{array}{l}-486 \\
(290) \\
{[0.094]}\end{array}$ & $\begin{array}{l}676 \\
(397) \\
{[0.091]}\end{array}$ & $\begin{array}{l}-153 \\
(181) \\
{[0.398]}\end{array}$ & $\begin{array}{l}261 \\
(199) \\
{[0.308]}\end{array}$ & 608 \\
\hline Poverty (<2 USD/day) & $\begin{array}{l}166 \\
(216) \\
{[0.462]}\end{array}$ & $\begin{array}{l}-484 \\
(290) \\
{[0.096]}\end{array}$ & $\begin{array}{l}672 \\
(396) \\
{[0.092]}\end{array}$ & $\begin{array}{l}101 \\
(140) \\
{[0.471]}\end{array}$ & $\begin{array}{l}-150 \\
(184) \\
{[0.436]}\end{array}$ & 608 \\
\hline
\end{tabular}

Notes: The table reports ordinary least squares estimates based on specification (2). Lottery indicates whether the individual has been randomly assigned to receive a lottery payout. Credit indicates whether the household head responded that she/he would not be able to "borrow money for an important expenditure". Standard errors are clustered at the household level and given in parentheses. In square brackets $p$-values of the null hypothesis of no effect are provided. For the main effect of Lottery Win and interactions with Lottery Win these are calculated as randomization inference $p$-values, for all other coefficients they are calculated analytically based on the reported clustered standard errors. Mean WTP among all lottery losers, and the number of observations, are reported at the bottom of the table. 


\begin{tabular}{|c|c|}
\hline Variable & Explanation \\
\hline Cognitive skills & $\begin{array}{l}\text { The normalized index combining three indicators: EGRA, EGMA and Raven score (see below for } \\
\text { details of these indicators). To calculate the normalized index we first normalize each indicator } \\
\text { by subtracting its sample mean and dividing by its standard deviation; then we take the average } \\
\text { of the three normalized indicators; and we normalize again. }\end{array}$ \\
\hline Credit constraint index & $\begin{array}{l}\text { Both girls and household heads were asked separately: 'If you needed to borrow money for an } \\
\text { important expenditure (e.g. health or school related expenditure), how easy would it be for you to } \\
\text { borrow the money?' with answer options being 'easy','not easy, but possible', and 'not possible'. } \\
\text { We generate indicators for whether respondents state it is not possible and anything but easy, } \\
\text { respectively. We calculate the index by first normalizing each indicator by subtracting the sample } \\
\text { mean and dividing by its standard deviation; then taking the average of the four normalized } \\
\text { indicators, and normalizing again. If only some of these dummies are available we impute the } \\
\text { missing ones at the sample mean. The resulting index is increasing the more constrained the } \\
\text { girl/household head is. }\end{array}$ \\
\hline Distance to school & For girls enrolled in school, it is the shortest time (in minutes) it takes to reach school. For girls \\
\hline
\end{tabular}
For girls enrolled in school, it is the shortest time (in minutes) it takes to reach school. For girls out of school, it is the average time it takes for (in-school) girls within the same village to reach school.

EGRA

$E G M A$

Gender attitude

Girl: No credit access

Girl: No easy credit access

Lottery win

HH kids (no)

HH kids $(f / m)$

HH: No credit access

HH: No easy credit access

Illness

Patience

Per Capita Expenditure

Poverty ( $<2$ USD/day)

Raven Score

Returns Second. E.

Risk Aversion

Tutoring
Number of words per minute that the girl is able to read in the reading test. The test contained 50 words that the respondent was asked to read out. We divide the number of correctly read words by the time it took for the respondent to read them to obtain 'words per minute'.

Score measuring numeracy skills based on a Math exam (EGMA). The EGMA had 5 sections. Some sections had 10 and some had 20 questions. We aggregate the scores by dividing the number of correct answers given in each section of the exam by the total number of questions in the relevant section (either 10 or 20) to obtain the percentage of correct answers in each section. Then, we take the average of the 5 sections, giving equal weight to each section, to obtain the total score for EGMA.

Girls were asked the following questions: 'Who should earn money for the family?', 'Who should have a higher level of education in the family?', 'Who should be responsible for washing, cleaning and cooking?', 'If there is no water pump or tap, who should fetch water?', 'Who should be responsible for feeding and bathing children?', 'Who should help the children in their studies at home?', 'Who should be responsible for looking after the ill persons?'. The possible responses were 'Males', 'Females', 'Both males and females'. For each variable, we generate a dummy variable equal to 1 if the response is 'Both males and females'; we then take the average of these indicators, corresponding to the fraction of statements to which the girl responded with genderneutral attitudes.

Dummy indicating if the girl reported that it would be 'not possible' to borrow money for an important expenditure (e.g. health or school related expenditure).

Dummy indicating if the girl reported that it would be 'not easy, but possible' or 'not possible' to borrow money for an important expenditure (e.g. health or school related expenditure). Dummy indicating if the individual has been randomly assigned to receive a lottery payout. Number of household members younger than 20, as reported by the household head. Percentage of females among household members younger than 20.

Dummy indicating if the household head reported that it would be 'not possible' to borrow money for an important expenditure (e.g. health or school related expenditure).

Dummy indicating if the household head reported that it would be 'not easy, but possible' or 'not possible' to borrow money for an important expenditure (e.g. health or school related expenditure).

Dummy indicating if the girl reported having had any serious illness in the last year.

The girl's response to the question 'On a scale from 0 (very patient) to 10 (very impatient), which number do you give yourself?', inverted.

Monthly household consumption (in Tanzanian Shillings) as reported by the household head, divided by the number of people living in the household. Consumption items include: food (purchased), food (produced), tobacco, alcohol, fuel, cosmetics/toiletries/hairdressing, entertainment, transportation, electricity, salary of maid, household utensils, household furniture, household textiles, clothing, rent (for housing), material for ritual ceremonies, alms and gifts, brideprice, legal expenses.

Dummy indicating if the per capita daily expenditure is less than 2 USD PPP.

Number of correct answers (0-7) in a test using Raven's Progressive Matrices.

The girl respondent was asked two separate questions: 'If you were to stop studying once you complete primary school, do you think you will be working (in an income generating activity) by the time you are 25 years old?'; 'If you were to stop studying once you complete secondary school, do you think you will be working (in an income generating activity) by the time you are 25 years old?' Based on these, we generate a dummy indicating if the girl reported that she would not be able to get a job at age 25 if her highest qualification is a primary school degree, but she would be able to do so with a secondary school degree.

The girl's response to the question 'On a scale from 0 (not at all willing to take risks) to 10 (very willing to take risks), which number do you give yourself?', inverted.

Dummy indicating if the girl reported that she attended any tutoring or study group during the past year. 


\section{B Implementation details}

\section{B.1 Sample Selection}

1. We selected, by simple randomization, 8 out of 20 of the NGO's branch offices in which to conduct the study.

2. The NGO's field staff identified 105 villages that were close to potential treatment schools, to participate in the study.

3. We select 69 villages to receive the program, as follows:

(a) For each village, the NGO's field staff provided the identity of the nearest school. In most cases, multiple villages share the same nearest school (or two schools on the same campus). The program was to be assigned at the school/campus level, so either all villages or no villages connected to a given school/campus would receive the program. We call each group of villages connected to a given school a "cluster."

(b) When a branch had schools connected to only one village, we created clusters by grouping such villages in twos or threes.

(c) The program as a whole was randomized at the cluster level.

(d) We only measure WTP for the program in villages assigned to receive the program, so our analysis data comes only from the program villages. Our sampling of study villages is thus clustered at the school/campus level, within the set of study branches.

(e) We randomized the price of the program (to be revealed after the WTP elicitation) within cluster. There were two prices, zero TSh or 3,000 TSh. Thus for each school some villages were assigned free clubs, and others paid clubs. This distinction is not relevant for our analysis as we use only the WTP data, measured prior to the revelation of the club price.

4. In these villages we conduct a census, leading to a sample of 5,968 girls.

5. We screen for eligibility, excluding 920 girls, leading to a sample of 5,048 eligible girls.

6. We target a sample of 27 girls per village for the baseline, with the goal of not more than one girl per household (in case there are multiple eligible girls in a household). 58 villages have more than 27 households with at least one eligible girl, 4 have more than 27 eligible girls but fewer than 27 households, 7 have fewer than 27 girls even when repeatedly sampling from households. 
7. We randomly select a sample of girls that we will attempt to reach first for the baseline survey, along with a "reserve" list in case we cannot find somebody. So for the 58 villages with more than 27 households this involves selecting 27 primary households plus a reserve list, in the 4 villages with more than 27 girls but fewer households, we allow for sampling multiple girls in a household, and for the 7 villages with fewer than 27 girls, all girls are added to the primary list. This leads to a primary targeted sample of 1822 girls in the main sample. Of which 1566 are from villages which have more than 27 households with eligible girls, 108 are from villages which have more than 27 girls but fewer than 27 households, 148 are from villages which have less than 27 girls even when repeatedly sampling from households. There are 1263 girls in the reserve sample. Of which 1255 are from villages which have more than 27 households with eligible girls, 8 are from villages which have more than 27 girls but fewer than 27 households, 0 are by construction - from villages which have less than 27 girls even when repeatedly sampling from households. We cap the number of reserve girls at 25 per village.

8. Turning to those we actually find and survey in the baseline: Of the 1822 girls targeted, 1471 are in the baseline data. Another 193 girls in the baseline data are drawn from the reserve sample. In cases where we could not reach our target sample size from the baseline and reserve list, we allowed for convenience sampling of additional girls. There are 53 girls in the baseline data who fall into this category.

9. Because of challenges finding our targeted number of girls in some villages, we compensated by asking enumerators to keep sampling from the reserve lists in villages where we were able to reach 27 sampled girls without exhausting the primary targeted sample and reserve list.

10. This leaves us with a baseline sample of 1,717 girls. In 6 villages we have exactly 27 girls, in 47 villages we have fewer than 27 , and in 16 villages more than 27.

11. We collected baseline survey information from the girls as well as from their household heads.

12. All baseline girls get a lottery ticket that entitled them to a prize draw for 3,200 TSh if they came to an information meeting about the program, and that half of eligible attendees would win. We organized the information meetings which included the elicitation of WTP for participation in the program. All baseline girls were invited to attend, as well as any other girls living in the village. They were to be accompanied by a household member, ideally the household head.

13. Of the 1,717 girls in the baseline, 880 attended a WTP meeting, and in addition 252 
non-baseline girls attended a meeting. However as we do have individual or household covariates for the non-baseline girls, and they were not eligible for the lottery, we do not include them in the analysis.

14. Of the 880 baseline girls that attended a meeting, we have WTP data for 825 , we infer that the 55 for whom we do not have data chose not to participate in the WTP elicitation. The 825 girls correspond to 799 distinct households (in 22 households we have two girls and in 2 households we have three girls).

\section{B.2 Lottery implementation}

The lottery was intended to be implemented as follows. In each of the 69 villages, all baseline girls that attended the meeting to be eligible for the lottery, conducted via a prize draw, with a $50 \%$ chance of winning 3200 TSh (enumerators were to assign prizes to $50 \%$ of them, rounding up in case of an off number). In most villages this was implemented as intended but we encountered some minor implementation issues in some villages.

1. In 4 villages the lottery winners were not recorded by the enumerators, so we cannot analyze the lottery variable. This leaves us with 65 villages and 805 girls for whom we have WTP data.

2. In 45 villages, zero non-baseline girls won, and 50\% (rounding up) of baseline girls won the lottery. We infer that the lottery was implemented perfectly in these cases.

3. In 11 villages, zero non-baseline girls won, but the number of baseline girls that won was slightly different to the target (equal to $50 \%$ rounding up \pm 1 ).

4. In 3 villages, some non-baseline girls won. However the total number of winners within baseline was equal to $50 \%$, rounding up. In these cases we infer the lottery draw was implemented correctly except than non-eligible participants were entered mistakenly.

5. In 3 villages, some non-baseline girls won, and the number of winners within baseline was was slightly different to the target, equalling $50 \%$ of attendees, rounding up, \pm 1 .

6. In 1 village, some non-baseline girls won, and $12 / 18$ baseline girls and 5/12 non-baseline girls won the lottery (i.e. 17/30 attendees).

7. In 2 villages, zero non-baseline girls won, and the number of baseline girls that won is more than \pm 1 from the target (specifically, the winner/eligible ratios were $7 / 17$ and $5 / 19)$. 


\section{B.3 Balance checks}

Of 5,968 girls in the census, 5,048 were identified as marginalized, to be targeted for the program (see footnote 7). Appendix Table A.1 compares all census participants to the marginalized group, by presenting the average outcomes of a number of important covariates in both samples (columns 1 and 2), the difference between those averages conditional on village fixed effects and associated $p$-values (column 3), the normalized difference (column 4) and the number of girls who reported the covariate in either sample (column 5). Due to the screening, marginalized girls have fewer assets, fewer household members, and lower school attendance in the household.

Appendix Table A.2 compares the marginalized sample to the actual baseline sample, following the same format as Table A.1. Again we find statistically significant differences between the two samples. Girls in the baseline sample are more likely to come from households with illiterate female heads and households with fewer girls, and the composition of assets in the baseline sample differs from the sample of marginalized girls in the census. However, the magnitude of these differences is generally small, with normalized differences below 0.2 throughout.

Of the 1717 girls who participated in the baseline survey, 805 (around $47 \%$ ) also attended the WTP meeting, provided a WTP, and lottery winners were recorded in the village. Appendix Table A.3 shows that the girls who came to the WTP meeting were remarkably similar to the general population of baseline girls in terms of cognitive skills, socio-economic status, attitudes, schooling related variables and household characteristics. Exceptions to that rule are that girls who attended the WTP meeting had higher reading test scores, came from households with slightly more children and were less patient (judging by a normalized difference great than 0.1 or significant mean differences).

Appendix Table A.4 provides balancing tests for the lottery randomization. Recall that the design specified a treatment probability of $50 \%$, but this was not always implemented perfectly. We report the means of key covariates in the group of girls who did not win the lottery (column 1), who won the lottery (column 2), the difference between these means conditional on village fixed effects and associated randomization inference $p$-values (column 3 ), the normalized difference (column 4) and the number of girls who reported the covariate in either sample (column 5). The table reveals that the randomization was successful in creating a balanced sample as judged by the normalized differences being generally low, lower than 0.1. The only exception to that rule is that girls who did win the lottery did have lower Raven scores and were from smaller households. This needs to be kept in mind when interpreting the results. Also we note that only 3 of the 18 variables show statistically significant differences. This suggests that the randomization of the lottery treatments was 
unlikely compromised and supports our treating the lottery variable as exogenous. 


\section{B.4 WTP meeting script}

FIGURE B.2: WTP ELICITATION, ENGLISH TRANSLATION

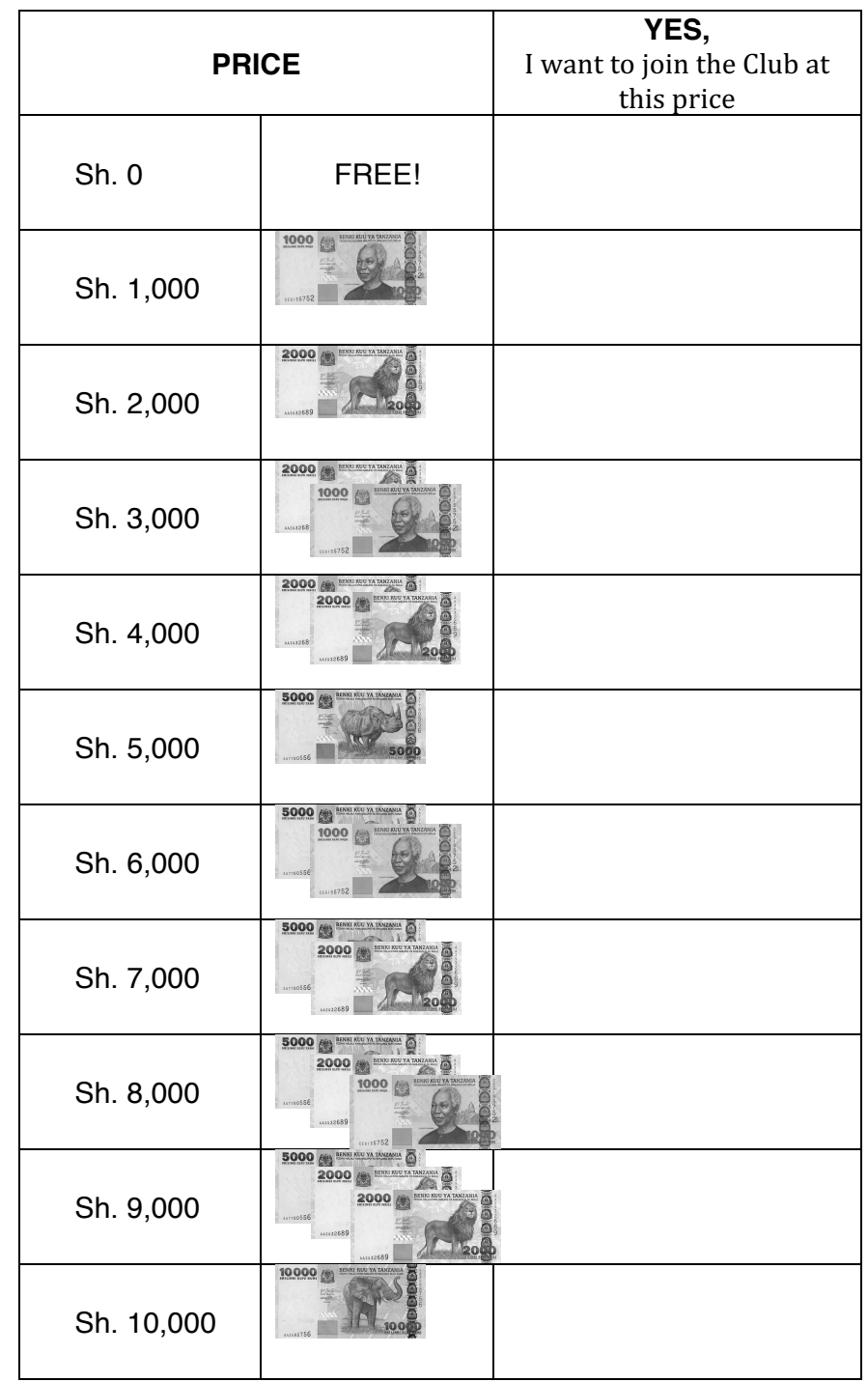

Why did you say that you would like to pay these prices?

a. I do not have more money than that.

b. I think that's the cost.

c. Another reason: Specify 


\title{
BEFORE THE START
}

\author{
KABLA YA KUANZA
}

AS GIRLS COME INTO THE MEETING, IDENTIFY THEM.

WATAMBUE WATOTO WANAPOKUJA KWENYE MKUTANO

If they were surveyed at baseline:

Kama walitembelewa wakati wa utafiti wa kwanza:

1. If they brought their lottery ticket, write the name and number of another piece of paper and put it in the plastic bag.

If they did not bring their lottery ticket, make a new lottery ticket where you write the name and a number and give this to the girl. Also write the name and number on another piece of paper and put it in the plastic bag.

Kama wataleta kadi zao za bahati nasibu, andika jina na namba kwenye kipande kingine cha karatasi kisha ukiweke kwenye mfuko wa plasitiki.

Kama hawakuleta kadi zao za bahati nasibu, tengeneza tiketi mpya za bahati nasibu ambapo utaandika jina na namba na umpatie mtoto. Pia andika jina na namba kwenye kipande kingine cha karatasi kisha kiweke kwenye mfuko wa plasitiki.

2. Find their corresponding sticker, stick it to an answer sheet and give them the sheet.

Zitafute stika zinazolandana na tiketi mpya, za bahati ibandike kwenye karatasi ya majibu na uwape karatasi hiyo.

3. Ask them to find a place to sit with their household head.

Waombe watafute sehemu watakayokaa na wakuu wao wa kaya

If they were not surveyed at baseline

Kama hawakutembelewa kwenye utafiti wa kwanza

1. Record their name, age, and household head name on a blank sticker, affix to an answer sheet and give them the sheet.

Andika majina yao, umri, na jina la mkuu wa kaya kwenye stika tupu, ibandike kwenye karatasi ya majibu na uwape karatasi hiyo.

2. Ask them to find a place to sit with their household head.

Waombe watafute sehemu watakayokaa na wakuu wao wa kaya.

\section{INTRODUCTION}

UTANGULIZI

Hello and welcome to the meeting. At this meeting we will do several things.

Habari na Karibuni kwenye mkutano. Katika mkutano huu tutafanya mambo kadhaa.

1. First we will explain and then find out the winners of the lottery.

Kwanza tutatoa maelezo na harafu tutawapata washindi wa bahati nasibu. 
2. Second we will explain the new BRAC study club to you Pili tutatoa maelezo kwenu ya klabu mpya za BRAC.

3. Last we will find out who is going to join the study club Mwisho tutaenda kujua ni akina nani watajiunga na klabu za masomo.

If you have any questions at any time, please raise your hand and we will answer.

Kama una maswali yoyote wakati wowote, tafadhari nyoosha mkono wako, uliza na tutakujibu.

\section{LOTTERY}

\section{BAHATI NASIBU}

The lottery tickets were given to girls who participated in our survey a few months ago, which is why not everybody has a ticket. Today, NUMBER OF TICKETS girls have entered the lottery draw, which means that NUMBER OF TICKETS/2 will win the prize of .... Tsh.

Kadi za bahati nasibu zilitolewa kwa watoto walioshiriki kwenye utafiti wetu wa kwanza miezi michache iliyopita, na ndiyo maana siyo watu wote wanazo kadi hizo. Leo, watoto $\{\mathrm{KI} I \mathrm{ASI}\}$ watakaoingia kwenye mchezo wa bahati na sibu inamaanisha kuwa nusu yao watashinda zawadi ya Sh. ..../=

We will do the lottery draw now.

Tutachezesha mchezo wa bahati na sibu sasa hivi.

DRAW THE LOTTERY TICKETS. IF N PEOPLE ENTERED, N/2 SHOULD BE DRAWN (ROUND UP TO NEAREST WHOLE NUMBER, I.E. IF 25 PEOPLE ENTER THERE SHOULD BE 13 WINNERS). ANNOUNCE THE WINNING TICKET NUMBERS.

CHEZESHA MCHEZO WA BAHATI NA SIBU. KAMA WATU X WALIINGIA KWENYE MCHEZO, TOA TIKETI (X/2) NUSU YA IDADI YA WATU WALIOINGIA KWENYE MCHEZO (IKARIBISHE KWENYE NAMBA KAMILI, MFANO; KAMA WATU 25 WALIINGIA KWENYE MCHEZO, INATAKIWA WATU 13 WAWE WASHINDI)

GIVE THE WINNERS THEIR MONEY AND ANNOUNCE:

WAPE WASHINDI PESA ZAO NA UWATANGAZE

You are free to do whatever you like with this money. pesa hizi uko huru kuzifanyia chochote upendacho

AND ASK THE PEOPLE TO SIGN THE PAYOUT SHEET NA UWAOMBE WATU KUWEKA SAHIHI ZAO KWENYE KARATASI YA MALIPO

\section{STUDY CLUB EXPLANATION}

Now, we will explain the BRAC study club program to you. This is a new program that is starting soon in this village. Any eligible girl can join, but you need to sign up today. We will explain how to sign up in a few minutes. 
MAELEZO YA KLABU ZA MASOMO

Sasa, tutauelezea kwenu mpango wa klabu za masomo za BRAC. Huu ni mpango mpya unaoanzishwa kwenye Kijiji hiki. Mtoto yeyote mwenye vigezo vilivyoainishwa anaweza kujiunga, lakini itatakiwa kujisajiri leo. Tutaeleza namna ya kujiandikisha ndani ya dakika chache zijazo.

\section{NOW THE CLUB LEADER OR PO SHOULD DESCRIBE THE CLUB}

\section{JOINING INFORMATION}

There may be a fee to join the study club, or it might be free to join. The price has already been set and is inside this envelope.

TAARIFA ZA KUJIUNGA

Kujiunga na klabu za masomo, kunaweza kuwa na ada, au inaweza kuwa ni bure. Bei tayari imeshapangwa na ipo ndani ya bahasha hii.

SHOW ENVELOPE WITH CLUB PRICE INSIDE

ONYESHA BAHASHA YENYE BEI YA KLABU NDANI YAKE

Before we open the envelope we are going to do a short survey to find out who wants to join the club, depending on the price. After the survey we will open the envelope and reveal the price. That will tell us who is going to join the club and who is not.

Kabla hatujaifungua bahasha tutaenda kufanya utafiti mdogo kujua ni nani anataka kujiunga na klabu, kulingana na bei. Baada ya utafiti tutaifungua bahasha na kuitambua bei. Hiyo itatuambia ni nani atajiunga na klabu na nani hatajiunga.

Here is how the survey works. Each girl has been given a sheet that looks like this HOLD UP LARGE SHEET. On this sheet is a list of prices. The price that is written in this envelope is one of those prices. It could be free!

Hivi ndivyo utafiti utakavyokuwa. Kila mtoto amepewa karatasi inayoonekana hivi INYANYUE JUU KARATASI. Kwenye karatasi hii kuna orodha ya bei. Bei iliyoandikwa kwenye karatasi hiii ni moja kati ya bei zote. Inawezekana ikawa ni bure!

For each price on the list, we want to know if you would join the club at that price. You should tick next to each price if you would be willing and able to pay that price to join the club.

Kwa kila bei iliyopo kwenye orodha, tunataka kufahamu kama ungependa kujiunga kwenye klabu kwa bei hiyo. Utatakiwa kutiki pembeni mwa kila bei kama ungependa na unaweza kulipia kujiunga na klabu kwa bei hiyo.

You will have to pay the joining fee at the first club meeting. Utatakiwa kulipia ada ya kujiunga kwenye mkutano wa kwanza wa klabu. 
Before we begin the survey, we are going to do a practice to help you to understand how the survey works.

Kabla hatujaanza utafiti, tutaenda kufanya zoezi litakalotusaidia kuelewa jinsi utafiti utakavyofanya kazi.

\section{SOAP PRACTICE - ZOEZI LA SABUNI}

The purpose of the game is for us to learn how much you are willing to pay for a bar of soap. This is the soap you can buy today:

Lengo la mchezo ni kwa sisi kujifunza kwa kiasi gani mngependa kulipa kununua kipande cha sabuni. Hii hapa ni sabuni ambayo leo mtaweza kununua:

\section{SHOW THE SOAP.}

IONYESHA SABUNI.

The amount that is charged here for this soap has been decided previously, and this price is hidden inside this envelope.

Kiasi cha bei ya sabuni hii kimeshaamuliwa kabla, na bei hiyo imefichwa ndani ya bahasha hii.

\section{SHOW PRICE ENVELOPE ONYESHA BAHASHA YENYE ORODHA YA BEI.}

We want to understand how much money people are willing to pay to get the soap. The price may be FREE, 100 TSh, 200 TSh, 300 TSh, 400 TSh, 500 TSh, 600 TSh, 700 TSh, 800 TSh, 900 TSh, or 1000Tsh. You have all received a sheet with all these prices written on it.

Tunataka kufahamu ni kiasi gani cha fedha watu wanapenda kulipa ili kupata sabuni. Bei inaweza kuwa ni BURE, Sh. 100, 200, 300, 400, 500, 600, 700, 800, 900, au 1000. Wote mmepata karatasi zilizoandikwa orodha ya bei zote hizi.

Here is how it works. For each of the prices, we want you to think about whether you would be willing and able to pay that price, TODAY, to get the soap. If you are willing and able to pay the price, you should tick the box.

Hivi ndivyo itakvyokuwa. Kwa kila bei tunawataka mfikiri kama mngependa na mnaweza kulipa bei hiyo ili kupata sabuni. Kama ungependa na unaweza kulipia bei hiyo, LEO, utatakiwa kutiki kwenye kisanduku.

\section{SHOW THE SOAP SHEETS. ONYESHA KARATASI YENYE ORODHA YA BEI ZA SABUNI}

So this is our list. You tick the boxes for prices that you are willing and able to pay today. So if you can and want to pay maybe 200 TSh for the soap, you tick the box next to 200 TSh and the 
boxes above.

If you're able and wiling to pay $1000 \mathrm{TSH}$, you tick 1000 and all boxes above.

\section{SHOW ON THE SOAP SHEET WHICH BOXES SHOULD BE TICKED}

It's according to how much you can and how much you want to pay for this soap TODAY.

Kwa hiyo, hii hapa ndiyo orodha yetu. Utatiki visanduku kwenye bei ambayo ungependa na unaweza kulipa leo hii.

Kwa hiyo kama unaweza na labda unataka kulipia sabuni kwa Sh. 200, utatiki kisanduku cha mbele ya Sh. 200 pamoja na visanduku vilivyopo juu yake.

Kamwa unaweza na unapenda kulipia Sh. 1000, utatiki kisanduku cha mbele ya Sh, 1000 pamoja na visanduku vyote vilivyopo juu yake.

\section{ONYESHA KWENYE ORODHA YA SABUNI NI VISANDUKU GANI VITATAKIWA KUTIKIWA}

Ni kutokana na kiasi gani unaweza na kiasi gani unataka kulipa LEO kwa ajiri ya sabuni.

After you have all finished filling out the entire sheet, we will open the envelope and find out what the set price is. Everyone who marked on the sheet that he or she is willing to pay that price will get the soap and has to pay the fixed price from the envelope. Everyone who did not tick the box next to that price because they are not willing to pay that price will not get the soap and will not pay.

Mara wote mtakapomaliza kujaza karatasi yote, tutafungua bahasha na kuona ni bei gani imewekwa. Kila mmoja aliyeweka alama kwenye orodha kwamba angependa kulipa bei hiyo au zaidi atapata sabuni na atalipia bei iliyowekwa kwenye bahasha. Kila mmoja ambaye hakutiki kisanduku kilichopo mbele ya bei kwasababu hakupenda kulipa bei hiyo hatapata sabuni na hatalipa chochote.

To make sure that we all understand it, let's consider some examples:

Ili kuhakikisha kuwa wote tumeuelewa mchezo, hebu tuangalie baadhi ya mifano:

- First consider Neema. She will buy the soap if the price is $600 \mathrm{TSh}$. Of course this also means that she is willing to pay any price lower than 600 TSh. Therefore Neema should tick the boxes for $600,500,400,300,200,100$ and FREE. She should NOT tick the boxes for 700, 800, 900, 1000.

SHOW EXAMPLE A

- Kwanza mfikirie Neema. Atanunua sabuni kama bei itakuwa ni Sh. 600. Hata hivyo hii inamaanisha kuwa anapenda kulipa bei ambayo ni chini ya Sh. 600. Kwa hiyo Neema atatiki visanduku vyenye bei za Sh. 600, 500, 400, 300, 200, 100 na BURE. Hatatakiwa kutiki visanduku vyenye bei za 700,800,900, 1000. ONYESHA MFANO A

- Now consider Alice. Alice wants the soap but only has 200 Tsh so she cannot pay more than that today. What boxes should Alice tick? Please write down your answer on the sheet.

AFTER THE RESPONDENTS HAVE THOUGHT ABOUT IT, SHOW EXAMPLE B

- Sasa mfikirie Alice. Alice anataka sabuni lakini ana sh. 200 tu kwa hiyo LEO hawezi kulipia zaidi ya hiyo. Ni kisanduku gani Alice atatiki? Tafadhari andika jibu lako kwenye karatasi ya majibu.

BAADA YA WASHIRIKI KUFIKIRI KUHUSU HILI, ONYESHA MFANO B 
- Now consider Grace and Lucy. Grace only wants the soap if it is FREE, and she is not willing to pay anything to buy the soap. Lucy does not like soap and does not want it, even if it is FREE. What boxes should Lucy and what boxes should Grace tick? Please write down your answer on the sheet.

AFTER THEY HAVE THOUGHT ABOUT IT, SHOW EXAMPLE C.

So if someone really does not want the soap at all, like Lucy, she should not even tick the "Free" box. But someone who does like to get the soap when it's free should tick this box like Grace.

- Sasa mfikirie. Grace na Lucy. Grace anataka sabuni kama itakuwa ni BURE tu, na hangependa kulipia chochote kuipata sabuni. Lucy hapendi sabuni na haitaki hata kwa BURE. Ni visanduku gani Lucy na Grace watatakiwa kuvitiki? Tafadhari andika jibu lako kwenye karatasi.

BAADA YA KUWA WEMEWEZA KUFIKIRI JUU YA HILI, ONYESHA MFANO C

Kwa hiyo kama mtu hataki sabuni kabisa, kama Lucy, hatatakiwa hata kutiki kisanduku cha "BURE". Lakini kwa yeyote anayependa sabuni itakapokuwa ni bure atatiki kisanduku kama Grace.

- Now, consider Kate and Anna. Kate is willing to pay 800 TSh for the soap and Anna is willing to pay 600 TSh. This means their sheets would look like this:

SHOW EXAMPLE D.

So Kate will tick all boxes up to 800 and Anna all up to 600 . If the price in the envelope is 500 TSh, who will be able to buy the soap? And how much would each of them pay? Please write down the answers on the sheet.

GIVE THEM TIME TO THINK ABOUT IT

In this case, both Kate and Anna can buy the soap and both of them pay 500 TSh. Even though Kate was willing to pay more than Anna, both of them only have to pay the price that was written in the envelope.

- Sasa mfikiri Kate na Anna. Kate anapenda kulipia sabuni kwa Sh. 800 na Anna anapenda kulipa Sh.600. Hii inamaanisha kuwa karatasi zao zitaonekana hivi: ONYESHA MFANO D.

Kwa hiyo Kate atatiki visanduku vyote mpaka cha 800 na Anna naye vyote mpaka 600. Kama bei ya kwenye bahasha ni Sh. 500, nani wataweza kununua sabuni? Na kila mmoja wao atalipa kiasi gani? Tafadhari andika majibu kwenye karatasi. WAPE MUDA WA KUFIKIRI.

Kwa jinsi hii, wote wawili Kate na Anna wanaweza kununua sabuni na wote watalipa Sh. 500. Ingawaje Kate angependa kulipa zaidi ya Anna, wote wawili watalipa bei iliyoandikwa kwenye bahashatu.

- For the last question, I will show you two imaginary answer sheets. One of them has a mistake. SHOW EXAMPLE E.

Can you tell me which one has the mistake and what the mistake is?

So the sheet from person 1 contains a mistake. The mistake is that it does not make sense to be willing to pay 500, but not 400 . Similarly, it does not make sense to say you are willing to pay 100 TSh but not 0 TSh. So if the box for 500 TSh is ticked, all boxes above that should also be ticked.

- Kwa swali la mwisho, nitawaonyesha karatasi mbili za majibu. Mojawapo ina kosa. ONYESHA MFANO E. 
Mnaweza kuniambia ni ipi ina kosa na ni kosa gani?

Kwa hiyo karatasi kutoka kwa mtu wa kwanza inalo kosa. Kosa ni kuwa haileti maana kuwa ungependa kulipa Sh. 500 na siyo 400. Hivyo hivyo haileti maana kusema ungependa kulipa Sh. 100 na siyo 0. Kwa hiyo kama kisanduku cha Sh. 500 kimetikiwa, basi visanduku vyote vya juu yake pia vinatakiwa kutikiwa.

Are there any questions? Kuna maswali yoyote?

ONCE YOU ARE HAPPY THAT EVERYBODY UNDERSTANDS, MOVE ON TO THE NEXT PART

UTAKAPORIDHIKA YA KUWA KILA MTU AMEELEWA, NENDA SEHEMU INAYOFUATA

So to summarize, the price hidden in the envelope is the price for which you can buy the soap from us today. Everyone who ticked the box next to that price will have to buy the soap for that price. So you should only tick a box if you are willing and able to pay this price, TODAY. If you don't have any money on you right now, then you should only tick the box next to FREE. If you don't tick a box, it means you are not allowed to buy the soap for this price if this is the price hidden in the envelope.

Kwa hiyo kwa kuhitimisha, bei iliyofichwa kwenye bahasha ni bei ambayo unaweza kununua sabuni leo kutoka kwetu. Kila mmoja aliyetiki kisanduku kilichoko mbele ya bei hiyo atatakiwa kununua sabuni kwa bei hiyo. Kwa hiyo LEO utatakiwa kutiki kisanduku tu iwapo unapenda na unaweza kulipa bei hiyo. Kama kwa sasa hivi huna pesa yoyote, basi utatakiwa kutiki kisanduku cha mbele ya BURE. Kama hukutiki kisanduku, inamaanisha hautaruhusiwa kununua sabuni kwa bei hiyo kama bei hiyo ni ile iliyofichwa kwenye bahasha.

Ok, please now fill out your soap sheets together with your parent, marking all of the prices that you would be willing and able to pay. Raise your hand if you have any questions. Please remember that the price is already determined and is hidden inside this envelope so your answers cannot affect the price in any way. Please be quiet as you do the forms. We are interested in what YOU are willing to pay. There are no right or wrong answers.

Sawa, tafadhari sasa jaza karatasi yako yenye bei za sabuni pamoja na mzazi wako, wekea alama bei zote ambazo ungependa na ungeweza kulipa. Nyoosha mkono wako kama una maswali yoyote. Tafadhari kumbuka kuwa bei imeshapangwa tayari na imefichwa ndani ya bahasha kwa hiyo majibu yako kwa vyovyote vile hayata athiri bei zilizowekwa. Tafadhari kaa kimya unapojaza fomu yako. Tungependa kujua ni nini mngependa kulipa. Hakuna majibu sahihi wala ambayo si sahihi.

NOW GIRLS SHOULD RESPOND ON THEIR "SOAP FORMS" FOR EACH OF THE PRICES WHETHER THEY ARE WILLING TO PAY THAT AMOUNT.

SASA WATOTO WATATOA MAJIBU YAO KWENYE KARATASI ZA BEI ZA SABUNI KWA KILA BEI KAMA WANGEPENDA KULIPA KIASI HICHO 
Below the price list, there is a question about why you indicated that you are willing to pay this price and lower prices, but not prices that are higher. There are some answers that you can choose from: the first answer is that you don't have more money than this right now, the second answer is that you think this is how much the soap is worth. If you have any other reasons you can write those down after answer $\mathrm{C}$, where you can specify the reason. Please circle the letters for the answers that are true for you. You may circle as many answers as you like.

Chini ya orodha ya bei, kuna swali kuhusu kwa nini ulionyesha kuwa unapenda kulipa bei hii na bei za chini yake, lakini siyo bei zilizopo juu ya hapo. Kuna baadhi ya majibu ambayo unaweza kuchagua kutoka humo: Jibu la kwanza ni kwamba kwa sasa huna pesa zaidi ya hizi, jibu la pili ni kwamba unafikiri hivi ndivyo thamani ya sabuni inatakiwa kuwa. Kama una sababu zozote unaweza kuziandika zote baada ya jbu $\mathrm{C}$ ambapo unaweza kuthibitisha jibu. Tafadhari zungushia herufi za majibu ambayo ni ya kweli kwako. Unaweza kuzungushia majibu mengi kwa kadri upendavyo.

NOW GIRLS SHOULD RESPOND ON THEIR "SOAP FORMS" HOW MUCH THEY ARE WILLING TO PAY FOR THE SOAP. WHEN FINISHED, COLLECT UP THE FORMS AND OPEN THE SOAP PRICE ENVELOPE. ANNOUNCE WHO IS GOING TO BUY THE SOAP AND MAKE THE TRANSACTIONS.

SASA WATOTO WATATAKIWA KUJIBU KWENYE "FOMU ZA SABUNI" NI KIASI GANI WANGEPENDA KULIPIA SABUNI. WAKIMALIZA, ZIKUSANYE FOMU ZOTE NA UFUNGUE BAHASHA YENYE BEI ZA SABUNI. MTANGAZE NI NANI ATAENDA KUNUNUA SABUNI NA UMPATIE SABUNI NAYE AKUPE PESA.

Ok, now we are going to do the same process, but this time we want to know what you are willing and able to pay to join the study club.

Sawa, sasa tutaenda kufanya kwa mtindo huo huo, lakini kwa wakati huu tutapenda kufahamu ni kiasi gani ungependa na unaweza kulipia kujiunga kwenye klabu ya masomo.

The price to join the study club could be FREE, 1000Tsh, 2000Tsh,... 10000Tsh. That price has already been set and is written in this envelope. Your answers cannot affect the price in any way.

Bei ya kujiunga na klabu ya masomo inaweza kuwa ni BURE, sh.1000, 2000,... 10000. Bei hiyo tayari imeshapangwa na imeandikwa kwenye bahasha. Majibu yako hayawezi kuathiri bei kwa namna yoyote ile.

We want to know, for each price, if you would be willing and able to pay that price to join the study club. We will collect the payment at the opening of the club. So you must be able to pay the fee on that day. BRAC may be charging some money for the participation in the club not to make profits, but to make the project more sustainable, so that more people can benefit from this program!

Tunataka kufahamu, kwa kila bei, kama ungependa na unaweza kulipia bei hiyo kujiunga na klabu ya masomo. Tutayakusanya malipo hayo wakati wa ufunguzi wa klabu. Kwa hiyo ni lazima uweze kulipia ada kwenye tarehe hiyo. BRAC inaweza kutoza kiasi cha fedha kwa kushiriki kwenye Klabu na siyo kutengeneza faida, lakini kufanya mradi kuwa endelevu, ili watu wengi zaidi waweze kufaidika na mpango huu! 
The process will be the same as for the soap. First, you fill out the form ticking all of the prices that you would be willing and able to pay at the opening of the club next week. Then we open the envelope and find out what the price is. Everyone who ticked that price will sign a contract that promises to join the club and pay the price at the first club meeting.

Utaratibu utakuwa sawa na ule wa sabuni. Kwanza, utajaza fomu ukitiki bei zote ambazo ungependa na unaweza kuzilipa wakati wa ufunguzi wa klabu wiki ijayo. Harafu tutafungua bahasha na kuona ni bei gani iliyopo. Kila mmoja aliyetiki bei hiyo atasaini mkataba unaoahidi kujiunga na klabu na kulipia bei hiyo wiki ya kwanza ya mkutano.

Let's begin. Please don't look at what other people answer, we are interested in what You think only and there is no right or wrong answer. Answer the questions together with your parent.

Hebu tuanze. Tafadhari usiangalie majibu ya mtu mwingine, tunapendezwa na jinsi unavyofikiri tu. Hakuna jibu saa hii wala lisilo sahihi. Jibu maswali pamoja na mzazi wako.

If you have any questions or need help, raise your hand and the staff will come to assist you. Kama una swali lolote au kutaka msaada, nyoosha mkono wako na kuna mtu atakuja kukusaidia.

\section{Price Revelation}

UTAMBUZI WA BEI

ONCE EVERYONE HAS COMPLETED THEIR FORMS, COLLECT THEM UP. THEN OPEN THE ENVELOPE AND ANNOUNCE THE PRICE. GO THROUGH THE FORMS AND PICK OUT EVERYONE WHO WAS WILLING TO PAY THAT PRICE. ANNOUNCE THEIR NAMES, THEN TAKE THE JOINING FORMS AND GET THE GIRL AND HOUSEHOLD HEAD TO SIGN THEM.

MARA KILA MMOJA ATAKAPOKUWA AMEMALIZA KUJAZA FOMU YAKE, ZIKUSANYE. HARAFU IFUNGUE BAHASHA NA ITANGAZE BEI. ZIPITIE FOMU ZOTE NA UCHUKUE YULE ALIYEPENDA KULIPIA BEI HIYO. WATANGAZE MAJINA YAO, HARAFU CHUKUA FOMU ZA KUJIUNGA NA UWAPE WATOTO NA WAKUU WAO WA KAYA KUZIJAZA.

Ok, the price is PRICE. The following people will be joining the club. LIST NAMES. Now we will sign the joining forms.

Sawa, bei ni BEI. Watu wafuatao watajiunga na klabu. ORODHESHA MAJINA. Sasa tutaweka sahihi kwenye fomu za kujiunga.

Thank you everyone for coming to the meeting. If you are joining the club, please come to the opening and bring your joining fee.

Asanteni kwa kila mmoja wenu kwa kuja kwenye mkutano. Kama unajiunga na klabu, tafadhari njoo kwenye ufunguzi na ulete ada yako ya kujiunga. 
FIGURE B.1: WTP ELICITATION

\begin{tabular}{|c|c|c|}
\hline \multicolumn{2}{|c|}{ BEI } & $\begin{array}{c}\text { NDIYO, } \\
\text { Nataka kujiunga na }\end{array}$ \\
\hline Sh. 0 & BURE! & \\
\hline Sh. 1,000 & & \\
\hline Sh. 2,000 & & \\
\hline Sh. 3,000 & & \\
\hline Sh. 4,000 & & \\
\hline Sh. 5,000 & & \\
\hline Sh. 6,000 & & \\
\hline Sh. 7,000 & & \\
\hline Sh. 8,000 & & \\
\hline Sh. 9,000 & & \\
\hline Sh. 10,000 & & \\
\hline
\end{tabular}

Kwanini ulionyesha kuwa ungependa kulipa bei hizi? (unaweza zungushia majibu mengi)

a. Sina pesa zaidi ya hiyo.

b. Nafikiri hiyo ndiyo gharama yake.

c. Sababu nyingine: Elezea. 